\title{
Role of Inflammation in Diabetic Retinopathy
}

\author{
Anne Rübsam ${ }^{1}$, Sonia Parikh ${ }^{1}$ and Patrice E. Fort ${ }^{1,2, *}$ \\ 1 Department of Ophthalmology and Visual Sciences, University of Michigan, Ann Arbor, MI 48105, USA; \\ aruebsam@med.umich.edu (A.R.); soniapar@umich.edu (S.P.) \\ 2 Department of Molecular and Integrative Physiology, University of Michigan, Ann Arbor, MI 48105, USA \\ * Correspondence: patricef@med.umich.edu; Tel.: +01-734-232-8225
}

Received: 15 February 2018; Accepted: 17 March 2018; Published: 22 March 2018

check for

Abstract: Diabetic retinopathy is a common complication of diabetes and remains the leading cause of blindness among the working-age population. For decades, diabetic retinopathy was considered only a microvascular complication, but the retinal microvasculature is intimately associated with and governed by neurons and glia, which are affected even prior to clinically detectable vascular lesions. While progress has been made to improve the vascular alterations, there is still no treatment to counteract the early neuro-glial perturbations in diabetic retinopathy. Diabetes is a complex metabolic disorder, characterized by chronic hyperglycemia along with dyslipidemia, hypoinsulinemia and hypertension. Increasing evidence points to inflammation as one key player in diabetes-associated retinal perturbations, however, the exact underlying molecular mechanisms are not yet fully understood. Interlinked molecular pathways, such as oxidative stress, formation of advanced glycation end-products and increased expression of vascular endothelial growth factor have received a lot of attention as they all contribute to the inflammatory response. In the current review, we focus on the involvement of inflammation in the pathophysiology of diabetic retinopathy with special emphasis on the functional relationships between glial cells and neurons. Finally, we summarize recent advances using novel targets to inhibit inflammation in diabetic retinopathy.

Keywords: diabetic retinopathy; neuroprotection; inflammation; neurodegeneration; pathophysiology; microglia; astrocytes; Müller glial cells; crystallins

\section{Introduction}

Diabetic retinopathy (DR) is the primary cause of visual impairment in the working-age population of the Western world [1]. Among microvascular complications related to diabetes mellitus such as nephropathy and neuropathy, DR is the most common. The prevalence rate for DR for all adults with diabetes aged 40 and older is $28.5 \%$ in the United States (4.2 million people) while estimated at $34.6 \%$ worldwide (93 million people) [2,3]. With the prevalence of diabetes expected to continue to rise, the prevalence of DR in the United States by year 2020 is expected to be 6 million persons with 1.34 million persons having vision-threatening disease [4]. The substantial worldwide public health burden of DR highlights the importance of continuously searching for new approaches beyond current standards of diabetes care.

Diabetic retinopathy is categorized based on the presence of ophthalmoscopically visible vascular (and closely associated) lesions. It is staged into a non-proliferative stage, characterized by vascular tortuosity, retinal hemorrhages, microaneurysms and lipid exudates; and a proliferative stage, where fragile new aberrant vessels develop (Figure 1). An important additional categorization in DR is diabetic macular edema (DME), a fluid accumulation into the neural retina, which leads to abnormal retinal thickening and often cystoid edema of the macula. DME could occur across all DR severity levels, of both NPDR and PDR and represents the most common cause of vision loss in 
patients with DR. While for diabetes the breakdown of the inner blood retinal barrier (BRB) is believed to play a dominant role in vascular leakage $[5,6]$, an important role of the outer BRB has recently gained momentum (for review [7]).

Clinical evidence indicates that there is a combination of capillary occlusion and an increased capillary permeability. The ability of vascular endothelial growth factor (VEGF) to promote both vascular permeability and angiogenesis made it a likely contributor to the vascular dysfunctions observed in severe DR [8,9]. Although significant success could be demonstrated with anti-VEGF therapy, a number of limitations exist ranging from the need for repeated intraocular injections, its efficacy only for late stages of the diseases, and most importantly the fact that only approximately half of the patients respond to the treatment [10].

With advancement in diagnostic tools, it has been demonstrated that patients with diabetes exhibit early signs of altered neuroretinal function even before the appearance of microvascular lesions [11]. Currently, there are still no therapies targeting these early stages of the disease to prevent alterations of the neuroretina and thereby preserve visual function. In the past decade, a variety of physiologic and molecular changes consistent with a role of inflammation have been found in the retinas or vitreous humor of diabetic animals and patients [12-18]. While the detailed mechanisms remain to be specified, these inflammatory changes seems to play a key role important in the development of DR as their inhibition has been shown to impact the development of retinal alterations in animal models of diabetes [19]. Studies using anti-inflammatory agents such as salicylates or minocycline in patients with DR gave further evidence that regulating the inflammatory response can be beneficial to prevent irreversible vascular and neuronal perturbations over time [20,21].

In this review, we analyze evidence that supports the hypothesis, that inflammatory-like processes play a critical role in the development of the early and late stages of the retinopathy with special emphasis on the role of inflammation in the impaired neuro-glial crosstalk in DR.

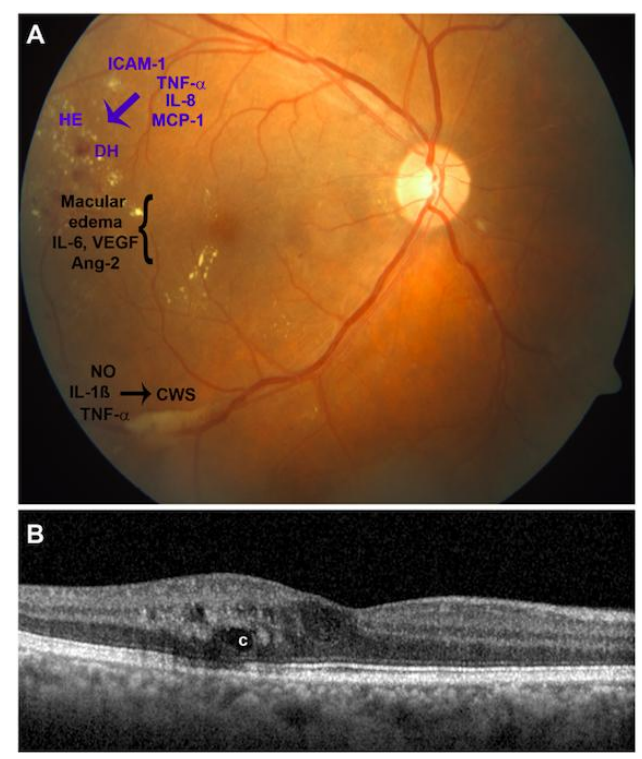

Figure 1. Clinical features of diabetic retinopathy and causative pro-inflammatory chemokines. (A) A fundus photograph shows the right eye of a 57-year-old man with 20/80 visual acuity and signs of severe non-proliferative diabetic retinopathy with non-significant macular edema (the region of macular edema is indicated by the bracket). Vascular pathologies are depicted in blue, whereas neurodegenerative features are black. Notable features include dot blot hemorrhages, DH; hard exudates, HE; cotton-wool spots, CWS. Each are associated with the upregulation of certain chemokines; (B) Optical coherence tomography with a horizontal scan through the central fovea reveals moderate thickening and edema of the macula with cysts; (C) Ang: Angiopoietin; IL: interleukin; TNF: Tumor Necrosis Factor; NO: nitric oxide; MCP: Monocyte Chemoattractant Protein. 


\section{Emergence of the Neurovascular Unit and Implications for Early DR}

Many DR studies, both clinical and using animal models focused on vascular dysfunction, such as impaired endothelial cells, death of pericytes, thickening of retina capillary basement membrane and altered tight junctions. However, diabetic microvasculopathy does not explain the susceptibility of peripheral nerves, cerebral complications or the early loss of retinal function. Beginning in the late 1990s, the concept of the neurodegenerative aspect of DR started to emerge. Several excellent reviews published in the last decade have summarized the evidence that neurons are vulnerable and die early in diabetic retinopathy, however, the pathophysiological mechanisms underlying this neurodegenerative process remain to be clearly elucidated [22,23]. While retinal ganglion cells (RGCs) are the earliest cells affected and have the highest rate of apoptosis [24,25]. An elevated rate of apoptosis has been also observed in the outer nuclear layer, with a reduction in photoreceptors seen between 4 and 24 weeks after diabetes onset [26,27]. Consistent with this, molecular analyses revealed that proteins important for photoreceptor function, such as rhodopsin, were affected before the appearance of microangiopathy in diabetes [28].

In addition to neuronal cell death, another early feature of diabetic-induced retinal neurodegeneration that has recently gained traction is glial cell activation and dysfunction. Müller glial cells (MGCs), the main glial cells of the retina, play a central role in retinal metabolism, making them highly sensitive to metabolic alterations such as those associated with diabetes. One of the early signs of retinal metabolic stress is the upregulation of glial fibrillary acidic protein (GFAP) by MGCs, an observation classically reported in animal models as well as in tissues from diabetic patients with no to mild NPDR [29,30]. Consequently, the resident immune cells in the retina, called microglia, also become activated and start to produce pro-inflammatory mediators, exacerbating neuro-glial and vascular dysfunction [31].

Those retinal abnormalities in neurons and glial cells are believed to drive a variety of functional changes that often precede clinically visible vascular lesions in DR. Among those functional changes are deficits pointing to ganglion cells such as the pattern electroretinogram (ERG), altered microperimetric [32] and perimetric testing [11]; or more generally the inner retina such as increased implicit times and reduction in oscillatory potentials in the multifocal ERG (mfERG) [33]. Other less cellular specific alterations have also been reported including abnormal dark adaptation, contrast sensitivity [34] and color vision [35]. Optical coherence tomography (OCT) is a widely utilized method for imaging the individual neural layers of the retina in many ophthalmic conditions. Several measures associated with OCT imaging are being explored as potential neuroretinal biomarkers of visual defects in eyes with DME and NPDR. Among those that are currently being assessed are ganglion cell/nerve fiber layer thinning, disorganization of the retinal inner layers, and photoreceptor disruption [36-38]. The latest progress in this domain is the technique of OCT angiography, which permits to combine with the anatomical observation the non-invasive study of the different layers of retinal microvasculature and choroid circulation via motion contrast imaging [39]. All these observations strongly suggest that diabetes directly affects the neuroretina rather than being solely secondary to the breakdown of the blood-retinal barrier (BRB). Several interconnected biochemical pathways, activated during diabetes, increase the expression of angiogenic and inflammatory mediators and induce aberrant growth factor signaling, all of which have been directly linked to neurodegeneration and vascular dysfunction (Figure 2).

Altogether these new insights into retinal physiology have led to the emergence of the concept that the retinal dysfunction associated with diabetes may be viewed as a change in the retinal neurovascular unit [40]. This concept of the neurovascular unit really emphasizes the intimate relationship between retinal neurons, (photoreceptors, horizontal and bipolar cells, amacrine and ganglion cells), their supporting cells (astrocytes and Müller glial cells), and the vascular beds (endothelial cells and pericytes). Proper function of all the elements of this unit is essential for normal retinal function as it allows the neural retina to adapt to varying physiological conditions, therefore, new therapeutic approaches promoting a "healthy" unit should be targeted. 


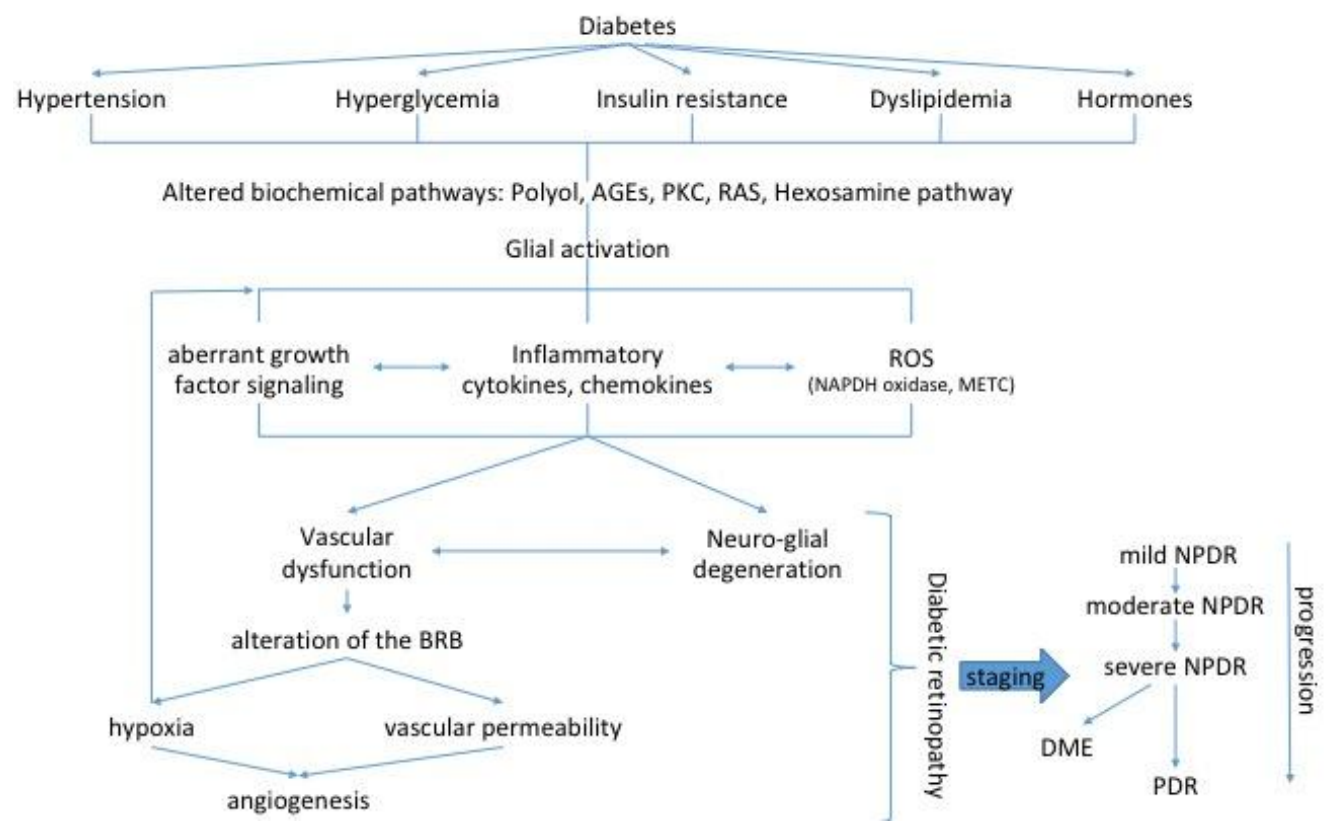

Figure 2. Schematic representation of pathogenic mechanisms leading to sight-threatening endpoints of diabetic retinopathy (DR): proliferative DR (PDR) and diabetic macular edema (DME). Metabolic alterations are first sensed by glial cells resulting in glial dysfunction, which induces inflammation, aberrant signaling of trophic factors and metabolic dysregulation all leading to neuronal apoptosis. Neurodegeneration also participate in blood-retinal barrier (BRB) breakdown, vasoregression and consecutive hypoxia, the main features of early microvascular abnormalities and the end stage neovascularization. According to the vascular lesions DR is staged by ophthalmoscopy in several stages of severity. AGE, advanced glycation end-products; PKC, protein kinase C; RAS, renin-angiotensin system, ROS, reactive oxygen species; NADPH, Nicotinamide adenine dinucleotide phosphate; mETC, mitochondrial electron transport chain; NPDR, non-proliferative DR.

\section{Role of Inflammation in Diabetic Retinopathy}

\subsection{Inflammation}

Inflammation is a non-specific response to injury or stress that includes a variety of functional and molecular mediators. When invading pathogens are involved, they are recognized by pattern recognition receptors, such as Toll-like receptors (TLRs) and the receptor of advanced glycation end products [36]. The molecules of the pathogens that bind to these receptors are called pathogen-associated molecular patterns (PAMPs) [41]. TLR activation or, in absence of pathogens, tissue stress alone, can lead to de-inhibition of the transcription factor Nuclear factor kappa B (NF- $\mathrm{kB}$ ), which translocates into the nucleus to stimulate transcription of pro-inflammatory cytokines, acute phase proteins and chemokines, such as IL-6, TNF- $\alpha$, IL-1 $\beta$, and monocyte chemoattractant protein-1 (MCP-1). All these pro-inflammatory chemokines play a major role in the recruitment and activation of monocytes and leukocytes and the subsequent inflammatory responses. Inflammation normally resolves promptly through a coordinated program that includes resolvins, lipoxins and protectins [42]. When not resolved in a timely fashion the typically beneficial effect of inflammation is lost and dramatic consequences ensues [43].

\subsection{Evidences of Inflammation in Diabetic Retinopathy Pathogenesis}

Increasing evidence points to inflammation as a critical contributor to the development of DR [44-46]. Many inflammatory cytokines and chemokines are increased in serum and ocular samples (vitreous and aqueous humor) from diabetic patients with DR (Table 1). 
Glial activation, or gliosis has been suggested to happen in patients with no clinical signs of DR. Increased levels of GFAP has indeed been reported in the aqueous humor of such patients [47]. Since Müller glial cells are a significant source of numerous factors including inflammatory modulators, this suggests that retinal glial cell activation might play an early role in the onset of the inflammatory process responsible for retinal damage at later stages of the disease. This hypothesis is further supported by the reported elevated levels at this stage of the disease of the adhesion molecules ICAM- 1 and the neutrophil chemotactic MCP-2, molecules also produced by MGCs and involved in leukostasis, another phenomenon observed early in DR pathology and associated with inflammation [48-50].

Various inflammatory cytokines-IL-1 $\beta$, IL-6, IL-8, TNF- $\alpha$ and MCP-1-have been reported elevated in ocular tissues from non-proliferative DR (NPDR) patients. One study detected even higher levels of IL-8 and TNF- $\alpha$ in diabetic eyes with NPDR than with active PDR [51]. The increase in these cytokines produced by activated microglia, endothelial cells, macroglia, and later even neurons, highlight the increased activity of these inflammatory cytokines in the early stages of DR and the progression of the inflammatory response throughout all cell types of the retina [52]. The accumulation of these inflammatory mediators has been proposed to contribute to early neuronal cell death in the retina in DM. Some of the cytokines identified, such as MIP-1, IL-1 and IL-3, are thought to also have a role in angiogenesis, as established in experimental ischemic mouse models suggesting that inflammation also contributes and precedes the development of neovascularization in PDR [21,53,54]. Significantly higher vitreous levels of neurotrophins (NTs), a group of specific growth factors, such as nerve growth factor (NGF), brain-derived neurotrophic factor (BNDF), NT-3, NT-4, ciliary neurotrophic factor (CNTF) and glial cell line-derived neurotrophic factor (GNDF) could be detected in DR patients, with even higher levels in NPDR compared to PDR [51]. This might be an attempt by glial cells such as MGCs to rescue compromised neurons during this early stage of DR.

In patients with PDR, increased vitreous concentrations of the aforementioned cytokines and neurotrophins along with other growth factors such as VEGF, platelet-derived growth factor (PDGF), insulin-like growth factor (IGF-1), basic fibroblast growth factor (bFGF) and hepatocyte growth factor (HGF) have been reported [55]. Of note, analysis of vitreous samples from PDR patients also revealed increased levels of soluble cytokine receptors, such as sIL-2R [56]. This increase constitutes a known negative regulatory mechanism of cytokine signaling, suggesting that counter-regulatory mechanisms of angiogenesis and inflammation exist within the eye. The development of PDR is a multistage event, including angiogenesis, in which basement membrane degradation, endothelial cell migration and proliferation, followed by capillary tube formation, occur. Matrix metalloproteinases (MMPs), which are important regulators of those migratory and tissue remodeling events, have been reported to be upregulated in PDR as well [57].

In patients with DME, levels of angiopoietin-2 (Ang-2), an important modulator of angiogenesis, are significantly elevated along with inflammatory cytokines and VEGF [12,58]. Currently there are no widely accepted valid biomarkers to monitor DR severity or efficiently classify patients for optimal assessment of treatment efficacy, but reports indicate, that VEGF, HGF, IL-6 and MCP-1 intravitreal concentration increase with the progression of DR from the non-proliferative form to active PDR [55,56]. Furthermore, IL-6 levels have been shown to positively correlate with retinal macular thickness [59].

A variety of the inflammatory mediators mentioned in the previous paragraphs are activated in DR, but the signaling involved in initiating this response is less clear. One of the caveats of using vitreous or aqueous humor levels to assess the expression of proteins associated with diabetes and DR, is the notion that the changes observed might just represent changes in circulating serum levels. Of note, it has been demonstrated, that the total vitreous protein content does not differ between NPDR and PDR patients [51], suggesting that increased vitreous protein levels present a real increase in secretion rather than just leakage of serum proteins into the vitreous because of a disrupted BRB.

Nevertheless, many features of inflammation including leukostasis, neutrophil and macrophage infiltration, complement and microglial activation, upregulation of cytokines, increased blood flow, vascular permeability and tissue edema have been described in animal models and human 
patients with DR [49,60-64]. Furthermore, inhibition or deletion of pro-inflammatory molecules has been demonstrated to dampen diabetes-induced vascular and neurodegenerative pathology in animal models of DR [65-67]. Thus, in the next sections we breakdown the specific contribution of inflammation to the main hallmarks of DR: angiogenesis and neurodegeneration.

Table 1. Overview over levels of inflammation-related cytokines, chemokines and growth factors in the vitreous or aqueous humor of human diabetic patients with different stages of diabetic retinopathy (DR). If only information on serum levels were available, it is mentioned specifically. $\uparrow$ upregulation, $\downarrow$ downregulation, $\leftrightarrow$ no change

\begin{tabular}{|c|c|c|c|c|c|}
\hline \multirow{2}{*}{ Factors } & \multicolumn{4}{|c|}{ Diabetic Retinopathy Stage } & \multirow{2}{*}{ References } \\
\hline & $\begin{array}{c}\text { Diabetics } \\
\text { without DR }\end{array}$ & NPDR & PDR & DME & \\
\hline AQP4 & $\uparrow$ & $\uparrow$ & not known & not known & [47] \\
\hline GFAP & $\uparrow$ & $\uparrow$ & not known & not known & [47] \\
\hline VEGF & $\begin{array}{l}\uparrow \text { serum } \\
\leftrightarrow \text { vitreous }\end{array}$ & $\uparrow$ & $\uparrow$ & $\uparrow$ & [68-70] \\
\hline IFN- $\gamma$ & $\uparrow$ & $\uparrow$ & $\uparrow$ & $\uparrow$ & {$[49,52,71,72]$} \\
\hline IL-1 $\alpha$ & $\uparrow$ & $\uparrow$ & $\uparrow$ & $\uparrow$ & {$[49,69]$} \\
\hline IL-3 & $\begin{array}{l}\uparrow \text { vitreous } \\
\downarrow \text { serum }\end{array}$ & $\begin{array}{l}\downarrow \text { vitreous \& } \\
\text { serum }\end{array}$ & $\downarrow$ serum & $\begin{array}{c}\uparrow \text { aqueous } \\
\text { no change vitreous }\end{array}$ & {$[49,73-75]$} \\
\hline s-IL2R & $\uparrow$ & $\uparrow$ & $\uparrow$ & not known & {$[56,73]$} \\
\hline MCP-2 & $\uparrow$ & $\uparrow$ & not known & not known & [49] \\
\hline ICAM-1 & $\uparrow$ serum & $\uparrow$ serum & $\uparrow$ & $\uparrow$ & {$[68,70,71]$} \\
\hline IL-1 $\beta$ & no & $\uparrow$ & $\uparrow$ & $\uparrow$ & {$[52,76]$} \\
\hline IL-6 & no & $\uparrow$ & $\uparrow$ & $\uparrow$ & {$[52,69,70,77]$} \\
\hline IL-8 & no & $\uparrow \uparrow$ & $\uparrow$ & $\uparrow$ & {$[51,69,77,78]$} \\
\hline IL-2 & no & $\uparrow$ & $\uparrow$ & not known & {$[52,79]$} \\
\hline IL-4 & no & $\uparrow$ & $\uparrow$ & not known & {$[52,80]$} \\
\hline IL-5 & no & $\uparrow \uparrow$ & $\uparrow$ & not known & [52] \\
\hline MCP-1 & no & $\uparrow$ & $\uparrow$ & $\uparrow$ & {$[49,77]$} \\
\hline TNF- $\alpha$ & no & $\uparrow \uparrow$ & $\uparrow$ & $\uparrow$ & {$[51,52,70]$} \\
\hline sTNF-R & no & $\uparrow$ & $\uparrow$ & not known & [49] \\
\hline RANTES & no & $\uparrow$ & $\uparrow$ & $\uparrow$ & {$[49,81]$} \\
\hline IP-10 & no & $\uparrow$ & $\uparrow$ & $\uparrow$ & {$[49,77,82]$} \\
\hline GM-CSF & no & $\uparrow$ & $\uparrow$ & not known & {$[49,69]$} \\
\hline PEDF & $\leftrightarrow$ vitreous & $\leftrightarrow$ serum & $\begin{array}{c}\uparrow \text { active PDR } \\
\downarrow \text { inactive PDR }\end{array}$ & $\downarrow$ vitreous & {$[12,83-86]$} \\
\hline IGF-1 & no & $\begin{array}{c}\text { conflicting } \\
\text { results }\end{array}$ & $\uparrow$ & not known & [87-89] \\
\hline PlGF & no & no & $\uparrow$ & $\uparrow$ & [90] \\
\hline IL-10 & no & no & $\uparrow$ & $\uparrow$ & {$[52,69,76]$} \\
\hline Complement factors & no & no & $\uparrow$ & $\uparrow$ & {$[17,63]$} \\
\hline bFGF & not known & not known & $\begin{array}{l}\text { conflicting } \\
\text { results }\end{array}$ & conflicting results & {$[89,91]$} \\
\hline CD40 & no & $\uparrow$ & $\uparrow$ & not known & [92] \\
\hline HIF- $1 \alpha$ & not known & $\uparrow$ & $\uparrow$ & not known & {$[93,94]$} \\
\hline
\end{tabular}

\subsection{Contribution to Vascular Pathology}

Evidence of a chronic low-grade inflammation of the retina of patients with advanced DR raised the question of its involvement in the development of edema and pathogenic vascularization $[95,96]$. 
Upregulated pro-inflammatory cytokines in the diabetic environment may directly induce vessel formation via engagement of target endothelial cells and indirectly, by inducing endothelial cells to produce pro-angiogenic mediators [97-99]. Endothelial cells are extremely susceptible to cytokines, especially IL-1 $\beta$, TNF- $\alpha$, and IFN- $\gamma$, which then induce production of endothelial cell-derived cytokines IL-8, MCP-1, and Regulated and normal T cell expressed and Secreted (RANTES). In vitro studies demonstrated that endothelial cells respond to cytokines rather than high glucose for induction of inflammatory pathways and apoptotic changes, suggesting that diabetes-related endothelial injury is primarily due to glucose-induced cytokine released by neighboring cells rather than a direct effect of hyperglycemia on endothelial cells themselves [100]. Upon cytokine stimulation they also secrete intracellular adhesion molecules such as ICAM-1 and VCAM-1, resulting in attraction of leukocytes, a process called leukostasis [101]. Indeed, animal studies have shown that 4 weeks after diabetes induction by streptozotocin-injection, before any vascular defects can be recorded, leukocytes start to adhere to the retinal capillaries with subsequent migration into the retina $[102,103]$. As a result, it has been proposed that the vascular wall integrity diminishes leading to increased vascular permeability. This allows extravasation of vascular fluid and migration of additional immune cells (neutrophils, monocytes) into the tissue. Concurrently, loss of capillary pericytes causes endothelial cell degeneration, which has been associated with accumulation of vacuoles and debris in the basement membrane resulting in its thickening, and ultimately vascular lumen occlusion [104-107].

The resulting retinal ischemia and hypoxia are strong stimulus for endothelial and glial cells to promote the expression of VEGF and other pro-inflammatory cytokines such as TNF- $\alpha$, IL-6, and IL-1 $\beta$, an effect which is in part mediated trough activation of the transcription factor hypoxia-inducible factor 1 (HIF-1) in the cells $[108,109]$. As inflammation increases in the diabetic retina it does so in a self-propagating manner. Indeed, among the ischemia-induced factors are chemokines such as MCP-1, responsible for attracting macrophages into less perfused areas [110]. Hypoxia-activated macrophages, glial cells and microglia cells produce TNF- $\alpha$ and IL- 6 and other inflammatory cytokines and growth factors, which in turn stimulate further release of MCP-1, IL- 6 and VEGF by endothelial cells, potentially resulting in increased vascular permeability as seen in NPDR and DME [21,110].

Angiogenic responses of endothelial cells are regulated by inflammatory cytokines and growth factors as well, resulting in the development of new vessel in PDR. The importance of inflammation for this phenomenon has been demonstrated by the fact that blocking inflammation reduces neovascularization. In a murine model of choroidal neovascularization, inhibition of monocyte recruitment by deleting MCP-1 [111] or deletion of ICAM-1 or CD18 led to significant inhibition of neovascularization [112]. Similarly, inhibition of Cyclooxygenase-2 (COX-2), which normally generates prostanoids, reduced the production of VEGF and subsequently vascular leakage in an animal model of DR. It also reduced retinal neovascularization in rodent models of ischemic proliferative retinopathy $[113,114]$. In addition, High-mobility group box-1 (HMGB1), a DNA-binding protein which facilitates gene transcription and which can be actively secreted by activated monocytes, macrophages and retinal endothelial cells has been linked to inflammation and angiogenesis in DR [115]. Extracellular HMGB1 functions as a pro-inflammatory cytokine and induces the expression of adhesion molecules and other cytokines and chemokines [116,117]. It also directly induces vessel formation by targeting endothelial cells or indirectly by induction of pro-angiogenic factors in endothelial cells and leukocytes [115]. Furthermore, VEGF itself also serves as pro-inflammatory molecule by promoting the expression of other pro-inflammatory cytokines such as I-CAM, MIP-1 $\alpha$, MCP-1 and IL-8 [60,118-120]. A role for inflammation in the development of pathological retinal neovascularization in DR was also seen in the rat model of oxygen-induced retinopathy (OIR), which utilizes hypoxia to generate neovascularization and capillary non-perfusion, thus mimicking what it seen in human patients with PDR. Gene expression of NF-KB and protein expression of IL- 6 and TNF- $\alpha$ were significantly increased in the retinas of OIR rats compared to controls [121]. Taken together, studies in the OIR models strongly support an interconnection between vascular alterations and inflammation, not only in the early stages of DR, but also in later stages of the disease, including neovascularization and edema. 


\subsection{Contribution to Neurodegeneration}

In addition to the vascular perturbations, the neurosensory retina is profoundly altered in diabetes. An emerging issue in DR research is the focus on the precise relationship between inflammatory alterations and the loss of neuronal function.

VEGF, which is a mediator of inflammation and angiogenesis, positively affects neuronal growth, differentiation and survival [122]. In vitro VEGF stimulates axonal outgrowth, improves the survival of ganglion neurons, and can rescue cerebral neurons from apoptosis induced by serum withdrawal. In vivo VEGF coordinates migration of motor neuron soma and local delivery of VEGF prolongs motor neuron survival [123]. The receptors for VEGF are present in normal retinal neuronal cells, indicating a possible functional role for VEGF in the neural retina [124]. Gene expression studies in the brain and retina also suggest that VEGF is upregulated by hypoxia preconditioning, a brief ischemic episode that protects neurons, against subsequent prolonged ischemia-reperfusion-related damage [123]. Aside from VEGF, insulin is another obvious pro-survival factor involved in diabetes and an interesting target to promote retinal neuron survival. Indeed, several groups have demonstrated that systemic and local administration of insulin can rescue retinal neurons from cell death in the diabetic rat retina [24,125]. Other neuroprotective factors include neuroprotectin D1 (NPD1) [126], brain-derived neurotrophic factor (BDNF) [127], GDNF [128], CNTF [129] and NGF [130], all of which have been suggested to be involved in the neurodegenerative and inflammatory process that occurs in DR. Early on, increased cytokine/growth factor expression may serve an adaptive function to maintain neuronal function but, over time, becomes maladaptive, at which point the role of VEGF and other factors is impaired and can lead to alteration of the BRB and induction of inflammatory responses.

Evidence further indicates that inflammatory processes themselves are activated in retinal neurons in response to diabetes. Hyperglycemia has been demonstrated to induce a pro-inflammatory phenotype in retinal neurons and their supporting glia in vitro [131,132]. While cytotoxic effects of high glucose treatment itself cannot be completely excluded, it has been demonstrated, that also in vivo hyperglycemia increased circulating cytokine concentrations by an oxidative mechanism in diabetic patients [133]. This suggests a causal role for hyperglycemia in the immune response associated with diabetes. In addition, immunohistochemical studies demonstrated translocation of NF-кB subunits into nuclei of retinal neurons in STZ-induced diabetic rats, suggesting that this pro-inflammatory transcription factor is also activated in neurons during diabetes [134]. Recent reports further provided evidence, that photoreceptors contribute to the inflammatory response in DR [135]. They are highly oxygen demanding cells and hence have shown to be the main sources oxidative stress in the retina in DR [136]. Moreover, it has been demonstrated, that photoreceptors themselves produce inflammatory cytokines such as ICAM-1, COX-2 and iNOS in experimental diabetes. They further release soluble factors in vitro that stimulate TNF- $\alpha$ production in leukocytes and endothelial cells, contributing to the vascular cell death in DR [137].

Consequently, pharmacologic interventions specifically targeting inflammation have been shown to reduce diabetes-induced neurodegeneration in animals studies and patients with DR. Yang et al., demonstrated that treatment with baicalein, a herbal medicine compound, suppressed diabetes-induced inflammatory cytokine upregulation, leading to reduced vascular leakage and ganglion cell loss in the retinas of diabetic rats [138]. The neuroprotective actions of the tetracycline derivative minocycline are mediated by the inhibition of microglial activation and of caspase- 3 activation in diabetic rats [21]. Furthermore, doxycycline, another tetracycline derivative was able to prevent neuronal function loss, assessed by frequency doubling perimetry, in patients with NPDR [139].

Despite the above success, other studies have demonstrated that diabetes associated neurodegeneration is not exclusively due to inflammation. Cluster of differentiation (CD) 40, a TNF receptor, which is expressed on various hematopoietic and non-hematopoietic cells, is expressed by MGCs in the retina [140]. Interaction of CD40 with his ligand CD154 not only regulates cellular and humoral immunity [141], but also activates inflammation by activating microglial cells [142]. Of note, inhibition of microglial activation in diabetic CD40 knockout (KO) mice prevented capillary 
degeneration, but despite a suppressed inflammatory response, the mice maintained ERG b-wave defects [143]. Similarly, diabetic mice deficient in nitric oxide generating inducible nitric oxide synthase (iNOS) did not develop the expected degeneration of retinal capillaries, leukostasis as well as ganglion cells loss, however they still presented with retinal functional impairment recorded by ERG [144]. More recently, inhibition of the receptor for advanced glycation end products [36] signaling pathway, which has been demonstrated to induce inflammatory changes in DR [145], did not protect from vision loss in diabetic animals [146]. These studies strongly support the notion, that inflammatory processes contribute, but not cause the development of DR. In this context other pathways such as oxidative stress have been shown to be important in the development of DR [147].

Furthermore, the initiation and regulation of inflammation is a considerably complex mechanism, e.g., many cytokines are known to activate NF- $\mathrm{kB}$ and other pro-inflammatory mediators; thus, inhibiting one component of this cascade will only be partially effective.

Nevertheless, from a therapeutic point, it is likely that identifying and halting key steps of the inflammatory process contributing to tissue destruction will help to control retinopathy. A more in-depth analysis of the role of inflammation in the neuro-glial crosstalk in DR will be discussed thereafter.

\section{Role of Glial Cells in Diabetic Retinopathy}

The two main retinal glial cells are Müller glial cells (MGCs) and astrocytes. Each cell type differs markedly in distribution, morphology, and function. Together with microglia, the main resident immune cells in the retina, they not only provide structural support, but they are also involved in maintaining the complex homeostasis of the retina by regulating the metabolism, the phagocytosis of debris and the cycling of neurotransmitters and trophic factors (Figure 3).

One of the first signs of inflammation in DR is the activation of glial and microglial cells. The conventional view is that microglia are the first responders, initiating an inflammatory response that participates to triggering MGCs gliosis [148]. Early histopathological studies reported that both macroglial and microglia cells show early structural changes after 4 weeks of experimental diabetes in rats. These studies originally suggested that diabetes affected the density of microglia and MGCs and that all glial cells sense metabolic changes similarly and at the same time [61]. However, most recently, several studies in animal models and post-mortem human tissues have suggested that the rapid microglial activation and its typical morphological changes can be detected prior to macroglial activation [149]. This notion is also supported by additional histopathologic studies showing that many inflammatory molecules, such as TNF- $\alpha$, can be detected early in the diabetic retina, often in association with microglia [138]. However, using mice with CD40 expression restricted to MGCs, Portillo et al., showed that CD40 in MGCs is sufficient to upregulate retinal inflammatory markers by microglia in experimental diabetes [142], supporting that the activation of microglial cells is, at least in part, dependent on other cell types of the retina. Alternatively to the CD40 dependent activation pathway, factors such as free fatty acids that are released by compromised neurons represent another mean for initial microglial activation [149]. Of note, other retinal cell types such as endothelial cells, astrocytes and neurons can respond to the initial activation of microglial cells by themselves participating and amplifying the inflammatory response. A support for this theory comes from the observation, that in vitro astrocytes require microglial presence to respond to inflammatory stimuli [150].

Early glial cell activation benefits the stressed retina, since activated glia phagocytose apoptotic cells, clear debris and cytotoxins, and secrete neurotrophic factors [151]. However, chronic gliosis in DR is detrimental, as activated glia may not properly regulate retinal blood flow or maintain the BRB. Moreover, gliotic cells secrete inflammatory cytokines, cytotoxic molecules and VEGF perpetuating both, vascular dysfunction and neurodegeneration [151]. 


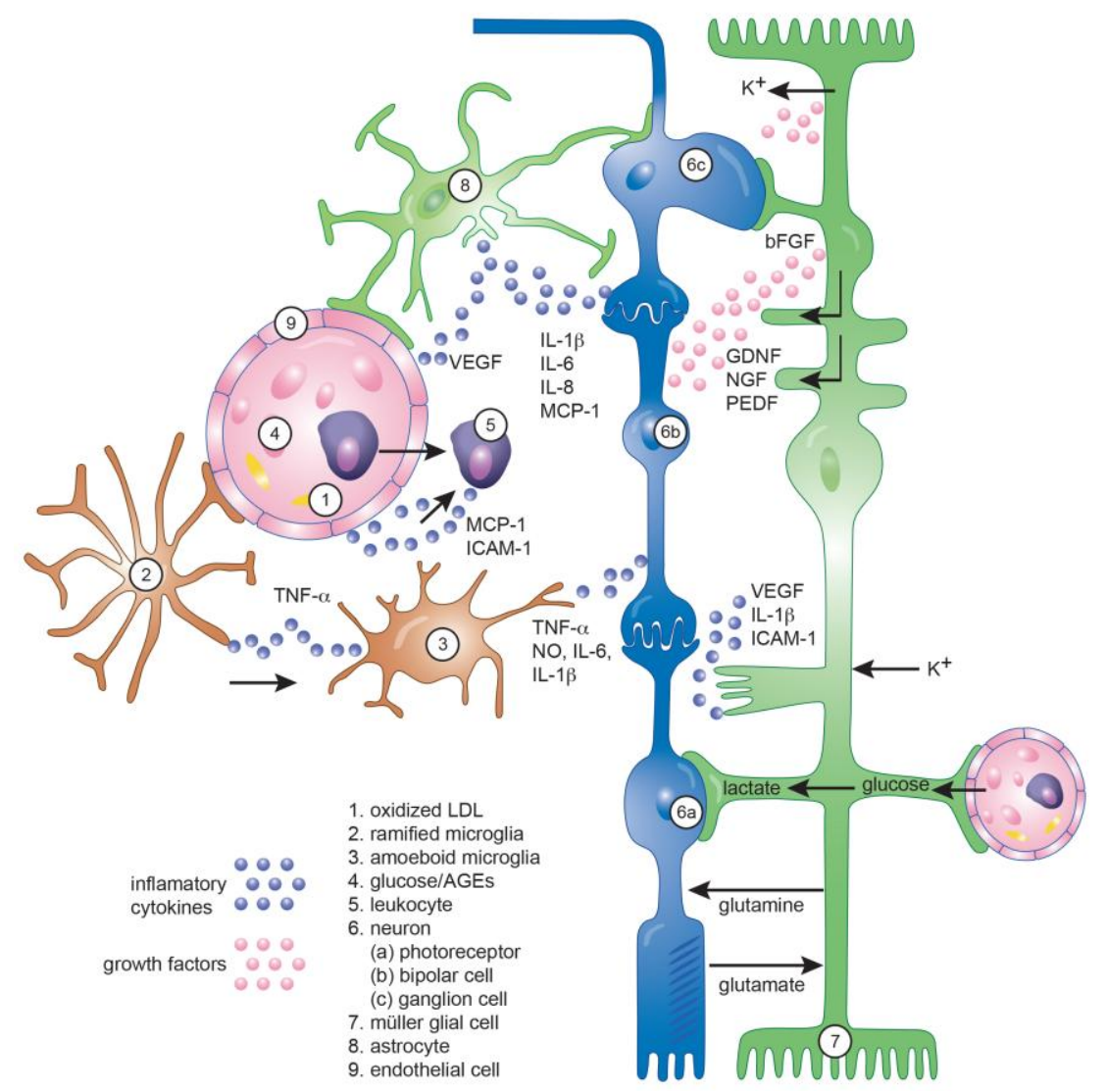

Figure 3. Schematic of a mammalian retina depicting the interactions between glia, neurons and endothelial cells with special regard to the inflammatory chemokines involved. Blood vessels and endothelial cells in pink (9), leukocytes in purple (5), macroglial cells in green $(7,8)$, microglia in brown $(2,3)$ and neurons in blue $(\mathbf{6 a}-\mathbf{c})$. Scheme showing kalium homeostasis, glutamate metabolism and the secretion of trophic factors, chemokines and interleukins. AGEs, advanced glycation end products.

\subsection{Microglia}

Microglia cells are the resident immunocompetent cells in the central nervous system. The most reliable characteristics differentiating microglia from invading monocytes are a low CD45 expression and a highly ramified, dendritic morphology [152]. In the developing retina, microglia are involved in the pruning of neuronal and vascular networks through the phagocytic removal of apoptotic cell debris [31,153]. In the adult retina, ramified ("resting") microglia reside in the inner and outer plexiform layers and they are an important source of neurotrophic factors that support neuronal survival. Resting microglia continuously monitor their environment and when activated, they shift towards an amoeboid morphology [154].

Although the precise mechanisms of glial activation in DR are not yet fully understood, it is likely that both genotypic variations and genetic susceptibility regulate individual microglial response in the course of DR [148]. Microglia, with their highly motile processes extending into the capillary wall, are assumed to be, together with Müller glia, the first detector of metabolic changes in diabetes [155]. They sense dyslipidemia, increases in ROS and cytokines, and the accumulation of AGEs. Amadori-glycated albumin, an AGE, was shown to specifically stimulate microglia to produce TNF- $\alpha$ in early stages of DR [156]. Once activated, microglia become mobile and migrate to the site of inflammation and will produce a wide range of pro-inflammatory cytokines, glutamate, ROS, nitrous oxide (NO) and proteases. Under chronic activation conditions, this cocktail can be extremely toxic to retinal ganglion cells, greatly exacerbating neuronal cell dysfunction $[138,149]$. Indeed, prolonged activation of microglia is associated with high levels of glutamate, iNOS and pro-inflammatory cytokines 
such as IL-1 $\beta$, IL-6, IL-12 and TNF- $\alpha$ which can culminate in the activation of caspases, exacerbating retinal neuron cell death retina [157].

Case studies exclusively using histological techniques on retinal cross-sections revealed increasing numbers of moderately hypertrophic microglial cells in the plexiform layers of NPDR patients [158]. They further showed that in tissues from PDR patients, clusters of microglial cells could be found surrounding ischemic areas and new vessels, while suggesting an even more significant rise in their total number [149].

\subsection{Müller Glial Cells}

Müller glial cells are the major glial cell type in the mammalian retina, representing $90 \%$ of the retinal glia. They form the supporting architectural structure radially stretching across the entire thickness of the neuroretina and participate in forming the outer and inner limiting membranes [159]. Müller glial cells also strongly link with retinal vessels and with the RPE, which establish connections to the subretinal space and choroidal vasculature [160]. Since Müller cells have contact to virtually every cell type in the retina they are uniquely positioned to perform a wide variety of functions necessary to maintaining retinal homeostasis. In the healthy retina, they recycle neurotransmitters, including glutamate thus preventing excitotoxicity; redistribute ions by spatial buffering, participate in the retinoid cycle, and regulate nutrient supplies $[160,161]$. Any disturbance to the retinal environment will influence Müller cells, which in turn will affect the entire retina [29].

Müller glia cells are deeply involved in DR, showing morphological and functional alterations from the early phases of the disease. The most striking example being that their size significantly increases in rodent models of diabetes, while a progressive increased expression of the stress marker GFAP becomes prominent in tissues from both animal models and diabetic donors [61].

In addition to GFAP upregulation, Müller cells acquire a complex and specific reactive phenotype, which is also characterized by induction of acute-phase response proteins and other inflammatory related genes [22]. In vitro studies have provided compelling evidence that Müller cells are a significant source for many growth factors and cytokines, when stimulated with stress conditions, including elevated glucose levels [132]. Considering that most of the growth factors, cytokines, and chemokines released by Müller cells have been identified in the vitreous of diabetic patients, it has led to the hypothesis that Müller cells contribute to the overall synthesis of these factors in vivo [162]. Non-targeted discovery approaches assessing the gene expression profile of Müller cells after 6 months of STZ induced diabetes, revealed that among 78 altered genes, one third are associated with inflammation, including complement factors, VEGF, ICAM-1 and IL-1 $\beta$ [163]. Of note, some of these cytokines in turn have been shown in other studies to stimulate production of other cytokines by Müller glia, suggesting a possible amplification effect. [164].

Taking into account their central role in maintaining the homeostasis in the retina and their contribution to the inflammatory response in DR, understanding Müller cell functions within the retina and restoring such function in DR could become a cornerstone for developing effective therapies to treat diabetic retinopathy.

\subsection{Astrocytes}

Like Müller cells, astrocytes are connected to retinal blood vessels and neurons and play a critical role in maintenance of the BRB, including regulation of blood flow [165]. Astrocytes also provide energy substrates to neurons and regulate the production of trophic factors and antioxidants. In contrast to Müller cells, they are largely restricted to the nerve fiber layer and ganglion cell layer. The distribution of retinal astrocytes is strikingly correlated with the presence and distribution of retina blood vessels, so vascularized areas of the retina are rich in astrocytes, while avascular zones such as the fovea, contain no astrocytes [166]. In response to injury or disease, they have been shown to upregulate the expression of various genes encoding cytokines, chemokines and elements of the complement 
cascade. Such response has been suggested to participate in compromising the integrity of the BRB and promoting retinal degeneration [167].

In response to the dysmetabolic and hypoxic diabetic environment, astrocytes become activated, also called reactive, and produce a variety of pro-inflammatory cytokines, such as IL-6, IL1 $\beta$, IL-8, COX-2, transforming growth factor- $\alpha$ (TGF- $\alpha$ ), epidermal growth factor (EGF), macrophage inflammatory protein $2 \alpha$ (MIP-2 $\alpha$ ) and VEGF $[168,169]$. Apart from inflammatory cytokines reactive astrocytes can secrete chemokines, including MCP-1, C-C motif chemokine ligand (CCL) 5, CCL20, C-X-C motif chemokine ligand (CXCL) 10, CXCL12, CXCL1, CXCL2, and CX3CL1 [170]. These chemokines are involved in the recruitment of microglia, monocytes/macrophages, T-cells, and dendritic cells, amplifying the inflammatory response. Over time astrocyte number seem to decrease in DR patients, as demonstrated by decreased GFAP expression, which then disrupts the inner BRB, contributing to vascular leakage in the retina [61].

\subsection{Role of Inflammation in the Neuro-Glial Crosstalk in DR}

Glial cells and neurons are intimately associated to make-up the neuro-glial unit. Glial cells are the interface between the neurons and the vasculature and are thus key regulators of neuronal function. Müller glial cells convey circulating glucose into the retina for ATP production and provide intermediary compounds such as lactate to neurons [64]. They play multiple key roles for retinal tissue homeostasis, from storing glycogen for conversion to lactate, to synthesizing retinoic acid from retinol, regulating extracellular ion concentrations to modulate plasma membrane polarization/depolarization, participating with neurons in the glutamate/glutamine cycle to control neurotransmission, and protect neurons from glutamate excitotoxicity [171]. Another important function of macroglial cells is to redistribute the neuronal metabolic by-products such as carbon dioxide and water from glucose metabolism, but also potassium and neurotransmitters associated with neuronal activity, into the blood and vitreous [161]. MGCs maintain proper retinal function by participating in a process known as "potassium spatial buffering", a process that redistributes and normalizes $\mathrm{K}^{+}$in the surrounding microenvironment to avoid prolonged accumulation of $\mathrm{K}^{+}$[172]. This response is coupled to the regulation of water homeostasis by the glial water channels aquaporins (AQP) such as AQP4 [173]. Macroglial cells, besides supporting the synaptic activity, maintain the integrity of the BRB and regulate the vasoconstriction related to neuronal activity, a process named neurovascular coupling by the release of neuroactive and vasoactive substances [174]. Macroglial and microglial cells also regulate the survival of neurons by a molecular network made up of several neurotrophic factors (BNDF, CNTF, GDNF; NGF, NT-3, and bFGF) [148]. Microglial and macroglial cells are further responsible for cellular debris phagocytosis and response to immunological damage [175]. They also play an active role engulfing synaptic material in a process termed synaptic pruning and referred to as the innate surveillance function of resident microglia $[176,177]$.

Diabetes also affects the neuro-glial unit by disrupting the communication between neurons and glia. In DR, accumulating evidence over the past decades have revealed that dysfunctional neuro-glial crosstalk, in part associated with inflammation, plays a critical role in the early course of the disease $[138,178]$. One of the first altered structural alterations in experimental and human DR is reactive gliosis of macroglial cells, mostly in the initial stages of DM [61]. Reactive gliosis may be interpreted as an effort to limit the extension of tissue damage but sustained inflammation in DR lead to the more severe forms of reactive gliosis [179]. Macroglial cells undergo further hypertrophy, lose their functionality, ultimately forming glial scars that are inhibitory to axonal regeneration and neuronal survival [162,180].

Microglial activation is the main mechanism by which neuroinflammation starts in response to nervous tissue perturbations [15]. Microglial activation in DR acts as a double-edged sword, as its primary function is neuroprotection. On the other hand, activated microglia produce pro-inflammatory mediators such as IL-1 $\beta$, IL-3, IL-6, TNF- $\alpha$, VEGF, lymphotoxin, MIP-1 $\alpha$, MMPs, NO, ROS and complement factors, primarily promoting neuronal cell death when sustained. $[138,149,157]$. The mechanism by 
which cytokines contribute to neural apoptosis is not clear but may involve the induction of excitotoxicity, oxidative stress or mitochondrial dysfunction [181-183]. A representative example of a neuron-microglia interaction is the FKN/CX3CR1 system, which provides a mechanism to modulate microglial activation by neurons. Fractalkine (CX3CL1 or FKN) exists on neuronal membranes and functions by signaling through its unique receptor CX3CR1 present on microglia. Several reports support the notion that FKN exerts an inhibitory signal on microglia [184]. It has been demonstrated, that increased inflammatory microglial responses in absence of the fractalkine receptor contribute to inflammatory-mediated damage to neurons in the diabetic retina [65]. Accordingly, microglial receptor proteins appear as important targets for the development of drugs to prevent or manage retinal neuroinflammation.

Next to microglia, astrocytes react becoming activated during diabetes and undergo a series of changes as mentioned earlier such as secretion various cytokines, chemokines, MMPs and elements of the complement cascade, contributing to neuronal degeneration $[138,167,168]$.

Notably, Müller cells exposed to hyperglycemic conditions also produce increased levels of pro-inflammatory molecules such as IL-1 $\beta$ and TNF- $\alpha$, which then induce expression of pro-death cytokine IL-8 [164]. Similar mechanisms have been proposed for other cytokines secreted by Müller cells such as IL-6, NO and COX-2 [132].

Water accumulation in retinal neurons and glial cells is another pathogenic factor involved in retinal degeneration during DR. Müller cells adapt their morphology to the increased size of activated retinal neurons by extending and thinning the inner stem process. The water flux through AQP4 is involved in the rapid volume regulation of retinal Müller cells in response to osmotic stress. Diabetes is known to enhance the amount of retinal expression of AQP4 and down-regulation of AQP4 exacerbated experimental DR through increased expression of pro-inflammatory factors [185]. Therefore, regulation of retinal function by AQP4 may attenuate diabetic retinopathy, offering a promising therapeutic strategy for diabetic retinopathy [185].

Neurodegeneration leads to the alteration of expression of growth factors (e.g., VEGF) by glial cells [186]. The release of VEGF by Müller cells under conditions stimulating gliosis is especially interesting, as it acts in two directions. VEGF signaling in Müller cells may represent a stress-responsive neuroprotective mechanism, particularly under hypoxic conditions. VEGF receptor 2 (VEGFR2)-mediated signaling in MGCs has been also shown to stimulate the production of BDNF and GDNF [178]. As a result, the loss of VEGFR2-mediated signaling in MGCs caused a significant elevation of apoptotic MGCs and neurons during experimental DR [178]. On the other hand sustained VEGF release also acts as a pro-inflammatory molecule by inducing the expression of other cytokines, thus exacerbating retinal neurodegeneration [187].

Conversely a growing body of evidence indicates that hyperglycemia-induced downregulation of a number of important neurotrophic factors, such as NGF, Pigment epithelium-derived factor (PEDF), CNTF, interphotoreceptor retinoid-binding protein (IRBP) and somatostatin, the loss of which may have a direct impact on neuronal survival [188]. Factors, such as PEDF, functions as an anti-inflammatory and anti-oxidative agent by inhibiting the activation of the NF-kB and Extracellular signal-regulated kinase 1 (ERK1) pathways. When secreted by Müller cells, this factor acts directly on PEDF receptors at the surface of RGCs $[189,190]$. PEDF levels were found to be decreased in cultured MGCs subjected to hyperglycemia and mild hypoxia [191,192]. However, under severe hypoxic conditions, PEDF was upregulated, potentially reflecting an attempt to rescue retinal neurons [192]. Why this observation does not translate in vivo, where decreased vitreous levels of PEDF are demonstrated also at later stages of DR such as PDR is not clear yet [83]. CNTF has been shown to directly prevent photoreceptor apoptosis and indirectly rescue neurons by stimulation of Müller cells to produce photoreceptor survival factors.

Altogether, studies clearly show how modulation of the inflammatory response by glial cells might act as an important target to prevent early neuronal damage in DR. 


\section{Emerging Trends in Inflammation-Related Mediators of Diabetic Retinopathy}

\subsection{Alpha-Crystallins}

The two small heat shock proteins $\alpha$-crystallins, $\alpha \mathrm{A}$ and $\alpha \mathrm{B},[193,194]$ have been widely studied for their roles in the lens, but we are just starting to understand their function in the retina. Recent studies revealed that $\alpha$-crystallins are rapidly upregulated in models of acute retinal injury, including light toxicity and trauma, suggesting that $\alpha$-crystallins play a role in the retina's response to cellular stress and damage [195-197]. We recently demonstrated that these chaperones were highly expressed in both RGCs and Müller glial cells of diabetic animals and human patients with DR [198]. Of note, $\alpha$ A-crystallins not only inhibit pro-apoptotic pathways in retinal neurons, but also act as a secreted pro-survival factor [198] and modulator of the expression of inflammatory molecules by glial cells (unpublished data), for the first time establishing a direct link between $\alpha$-crystallins and neuro-inflammation. Consistent with a critical role in glial cells, $\alpha$-crystallins have been reported to be upregulated in astrocytes of patients with Alexander disease and microglial cells of patients with Alzheimer's disease [199-201]. It has been hypothesized that the increased expression of $\alpha \mathrm{B}$-crystallin is part of the normal stress response to regulate aberrant protein aggregation and may prevent apoptosis in the face of the increased phagocytosis and protein aggregate load [202]. Overall, $\alpha$-crystallin chaperones affect microglial and astrocytic activation in an anti-inflammatory manner resulting in decreased cytokine production and tempering of the innate immune response. Further research, on the protective function of $\alpha \mathrm{A}$-crystallin should govern the development of specifically engineered crystallin proteins, which could be applied to the treatment of diabetic retinopathy and other neurodegenerative conditions.

\subsection{Matrix Metalloproteinases}

Matrix metalloproteinases constitute a large family of secreted and membrane associated zinc-dependent proteinases that degrade at least one component of the extracellular matrix (ECM). They are known to execute functions in motility, cell growth, injury response, and remodeling of the ECM by both, degrading it and controlling proteolysis of specific targets including cytokines, growth factors and adhesion molecules [203,204]. MMPs are highly sensitive to oxidative stress in the diabetic environment, with MMP-2 and MMP-9 being induced by increased ROS $[57,205,206]$. It has been suggested that these MMPs, especially MMP-9, can increase the inflammatory response by degrading some of the major components of the basement membrane, enabling invasion of the injured tissue by circulating immune cells. MMP-9 knockout-mice indeed showed significant reductions in the expression of inflammatory markers such as MIP-1 $\alpha$, MIP-1 $\beta$, and MCPs after spinal cord injury [207]. In addition, activated MMPs also contribute directly to angiogenesis and the increase in vascular permeability in DR by proteolytic degradation of occludin, disruption of the tight junction complex [57,208], and increased tissue levels of VEGF [209], making them interesting potential therapeutic targets.

\subsection{Toll-Like Receptors}

Toll-like receptors are pathogen-associated molecular pattern receptors that have been found on the surface of all cell types in the retina. Their activation results in the production of cytokines/chemokines in an NF- $\kappa B$ dependent manner [210]. Among the various TLRs, TLR-2 and TLR-4 have been most consistently associated with type 1 and type 2 diabetes. For example, genetic polymorphism in the TLR-4 gene is strongly associated with insulin resistance levels in patients with type 2 diabetes [211]. Additionally, TLRs also promoted the secretion of angiogenic growth factors in arterial endothelial cells [212] and led to choroidal neovascularization in vivo [213]. Human microvascular retinal endothelial cells demonstrated increased TLR-2 and TLR-4 expression when exposed to high glucose, an observation also associated with increased expression of pro-inflammatory molecules. Supporting a regulatory role of TLRs in this process, this effect was blunted by using a TLR4/2 inhibitory peptide or antioxidant treatment [214]. 


\subsection{Complement System}

While diabetes is not considered a complement-mediated disease, some data suggest a link between DR progression and complement dysregulation. Evidence for such a link comes from the observation of increased expression of several complement factors in the vitreous of patients with DR. Among over 30 small proteins and protein fragments identified as part of the complement pathway, some of the key regulators have been reported increased in PDR patients: C3, C4b, C9, and factor B (CFB) $[215,216]$. C5 cleavage, along with C3, is considered one of the two critical steps for the full activation of the complement pathways. A fully activated complement system results in the formation of the membrane attack complex (MAC or C5b-9) that can kill pathogens but also under certain conditions host cells, thus could play a role in neurodegeneration and vascular permeability. Additionally, cleavage products $\mathrm{C} 3 \mathrm{a}$ and $\mathrm{C} 5 \mathrm{a}$ have a chemotactic effect on neutrophils, mast cells, and lymphocytes, potentially exacerbating the inflammatory response. Finally, Müller glial cells constitutively express $\mathrm{C} 5 \mathrm{aR}$, the expression of which is further increased by high glucose exposure, and associated with release of IL- 6 and VEGF by these cells, a mechanisms that could be involved in promoting the overt-inflammatory response observed in diabetes [217].

\section{Therapeutic Concepts in Diabetic Retinopathy}

\subsection{Current Therapies}

Several therapeutic approaches are in use clinically to inhibit the development or progression of DR. Metabolic control (tight glycemic control, regulation of blood pressure and hyperlipidemia) is associated with a lower risk of retinopathy $[218,219]$. Specific therapeutic options for DR include laser coagulation, surgery and intravitreal injection of anti-VEGF agents. Alternatively, intravitreal injections of steroids have been shown to reduce vascular permeability, reduce the breakdown of the BRB, inhibit leukostasis, inhibit VEGF gene transcription and translation [220]. Because of an increased rate of elevated IOP and cataract formation with steroids, the use of intravitreal steroids in clinical practice is currently reserved as the second-line treatment in patients with previous cataract surgery [221].

Unfortunately, all these therapeutic interventions have significant side effects and are only useful for patients with more advanced stages of DR, when vision is already compromised, and neurodegeneration already occurred. Considering the role of inflammation in the pathogenesis of DR, inhibiting the inflammatory pathway has been an appealing treatment option for DR in future practices.

\subsection{Inflammation-Targeting Therapies under Development and Validation}

\subsubsection{Nonsteroidal Anti-Inflammatory Drugs (NSAID)}

Clinically the beneficial effect of NSAIDs, that inhibit COX enzyme-mediated ICAM-1 expression and leukostasis [222,223], has been suggested in a study reporting reduced incidence of DR in patients taking salicylates for the treatment of rheumatoid arthritis [20]. This finding encouraged the launch of clinical trials, which showed the development of retinal microaneurysms is only significantly attenuated in patients with early stage of DR when treated with high dose of aspirin ( $900 \mathrm{mg} /$ day) [224,225]. Alternatively, while systemic administration of specific COX-2 inhibitors is made impossible by increased incidence of heart attacks and strokes [226], preclinical studies with topical administration were shown to reduce signs of DR $[227,228]$.

\subsubsection{Blocking Inflammatory Molecules}

The effect of anti-TNF $\alpha$ therapy has been studied in a few clinical cases. Patients with refractory DME treated with intravitreal Etanercept (TNF $\alpha$ inhibitor) showed no statistically significant improvement [229]. Infliximab, a TNF $\alpha$ neutralizing antibody on the other hand improved visual acuity and reduced macular thickness in 4 patients who failed to improve in response to laser 
photocoagulation treatment [230]. Larger trials are needed to determine the efficacy of these drugs in DME patients.

Alternatively, a pilot study on the efficacy and safety of a selective IL-1 $\beta$ antibody, Canakinumab (Novartis, Basel, Switzerland), for the treatment of patients with proliferative DR showed stabilization but no regression of retinal neovascularizations, along with promising effects on diabetic macular edema reduction [231]. Similarly, a clinical trial in DME patients comparing an oral inhibitor targeting the receptors for MCP-1, CCR2/CCR5 (Pfizer, New York, NY, USA) to intravitreal anti-VEGF therapy showed non-inferiority of the study drug regarding gain in visual acuity and reduction in central retinal thickness [232].

Leukostasis, one of the early steps of inflammation, is dependent on specific integrins on the endothelium to trigger leukocyte adhesion and infiltration [233]. The DEL MAR Phase $2 b$ trial using an integrin antagonist, Luminate, ALG-1001 (Allegro Ophthalmics, San Juan Capistrano, CA, USA) as sequential therapy to a single anti-VEGF injections in DME patients compared to anti-VEGF monotherapy reported sustained and equal visual acuity gains for both treatments [234].

\subsubsection{Inflammatory Growth Factors}

Angiopoietins represent a family of inflammatory growth factors that bind to the receptor tyrosine kinase Tie2 and are important modulators of angiogenesis. A recent study also reported that Ang-2 promotes adhesion of monocytes and the subsequent tissue inflammation by modulating the TNF- $\alpha$-induced expression of ICAM-1 [235]. Thus, the Ang-2 pathway is currently being targeted in a recent ongoing clinical trial with a Tie-2 activator (AKB-9778, Aerpio Therapeutics, Cincinnati, OH, USA) in patients with NPDR, where improvements in DR severity will be evaluated. A previous study already demonstrated a significant benefit of AKB-9778 combined with anti-VEGF therapy over anti-VEGF monotherapy in the reduction of DME with a trend toward improved visual acuity [236].

\subsubsection{The Renin-Angiotensin System (RAS)}

Specific blockade of the RAS with the Angiotensin II receptor type 1 (AT1R) blocker (Losartan, Candesartan) and angiotensin-converting enzyme inhibitor (Enalapril) has been shown to reduce the risk of onset and the progression of retinopathy in patients with type 1 and 2 diabetes [44,237,238]. In another clinical trial involving 285 type 1 diabetic patients with normotensive and normoalbuminuria, blockade of RAS with Losartan or Enalapril significantly reduced the progression of retinopathy by 70\% and 65\% respectively [238]. However, the Diabetic Retinopathy Candesartan Trials which enrolled 3326 patients with type 1 diabetes and 1905 patients with type 2 diabetes, did not observe such a dramatic effect. It has been demonstrated, that Candesartan treatment reduced the incidence of DR but did not prevent progression of DR [237]. Further studies are needed to resolve the discrepancy between the above trials and to fully evaluate the beneficial effect of RAS blockade before its clinical usefulness is fully demonstrated.

\subsubsection{Tetracyclines}

In addition to their antimicrobial activity, minocycline and doxycycline are known to possess several immunomodulatory and neuroprotective properties $[239,240]$, such as inhibiting the production of NO, cyclooxygenases, prostaglandins, IL-1 $\beta$ and TNF- $\alpha$ and caspases [21,241]. A single-center phase I/II clinical trial in 5 patients with DME showed that minocycline as primary treatment was associated with improved visual function, reduced central macular edema, and vascular leakage [242]. Another clinical trial demonstrated an improvement of perimetric parameters in patients with severe non-proliferative or non-high-risk proliferative DR treated with doxycycline compared to patients who received placebo. Of note, visual acuity and anatomical parameters (such as DR severity levels) were equal among both groups, which may relate to a differential effect of tetracyclines on different stages of DR dysfunction [139]. 


\subsubsection{Photobiomodulation}

Photobiomodulation (PBM), also known as low level laser therapy or far-red to near-infrared (FR/NIR) light therapy, consists of series of brief illumination with specific wavelengths of light (600-1000 nm) from a laser or a light emitting diode [243] and results in the activation of signalling pathways within the cell. It has been demonstrated, that it effectively inhibits diabetes induced increase in superoxide production, leukostasis and ICAM-1 expression in STZ induced rats, which resulted in a significant reduction in ganglion cell death and improvement of the photopic $b$ wave ERG amplitude [244]. A subsequent case series by the same group including 4 patients with type 2 diabetes with non-center-involving DME underwent treatment with PBM twice a day for 2-9 months, demonstrated statistically significant decrease in macular thickness by an average of $20 \%$, while the non-treated eye of the same patients featured a slight increase in thickness [245]. Further investigations, using larger patient populations, will be necessary to confirm the efficacy, establish the optimal treatment dose and duration, as well as identify and address potential safety concerns.

\section{Conclusions}

This review summarizes recent clinical and laboratory findings suggesting a pivotal role of inflammation in the pathophysiology of early DR. Many studies carried out in diabetic patients and diabetic animal models have shown that the diabetic milieu provoke increased local expression of inflammatory molecules, such as cytokines, chemokines, and growth factors involved in the development of DR. Glial cells are critically located between vasculature and neurons of the retina, having a key role in closely regulating the retinal microenvironment, which is often responsible for early harm of neuroretina in the beginning stages of DR. Recent findings implicate that these cells also initiate the inflammatory cascade. New technologies able to detect early alterations of the neuroglial unit support the idea that changes in the metabolism of glia cells and subsequent damages of retinal neurons precede microvascular impairment. Additional work has now been performed that suggests that in this manner anti-inflammatory drugs are promising future therapies to address both, vascular alterations and neurodegeneration. However, studies are still needed to better understand the exact molecular mechanisms underlying ocular inflammation in patients with DR.

Acknowledgments: This project and its authors were supported by a fellowship from the Deutsche Forschungsgemeinschaft RU 2020/2-1 (Anne Rübsam), Fight for Sight Grant-in-Aid, and NIH EY020895 (Patrice E. Fort). Patrice E. Fort is the guarantor of this work. We thank David Murrel for his assistance with the illustration.

Author Contributions: Anne Rübsam and Sonia Parikh wrote the manuscript. Patrice E. Fort obtained funding, wrote and edited the manuscript.

Conflicts of Interest: The authors declare no conflict of interest.

$\begin{array}{ll}\text { Abbreviations } \\ \text { AGE } & \text { Advanced Glycation End-product } \\ \text { AH } & \text { Aqueous Humor } \\ \text { Ang } & \text { Angiopoietin } \\ \text { AT1R } & \text { Angiotensin II Receptor Type 1 } \\ \text { AQP } & \text { Aquaporin } \\ \text { BDNF } & \text { Brain-derived Neurotrophic factor } \\ \text { bFGF } & \text { Basic Fibroblast Growth Factor } \\ \text { BRB } & \text { Blood-retinal Barrier } \\ \text { CCL } & \text { C-C motif ligand } \\ \text { CCR } & \text { C-C receptor } \\ \text { CD } & \text { Cluster of differentiation } \\ \text { CNS } & \text { Central Nervous System } \\ \text { CNTF } & \text { Ciliary Neurotrophic Factor } \\ \text { COX } & \text { Cyclooxygenase }\end{array}$




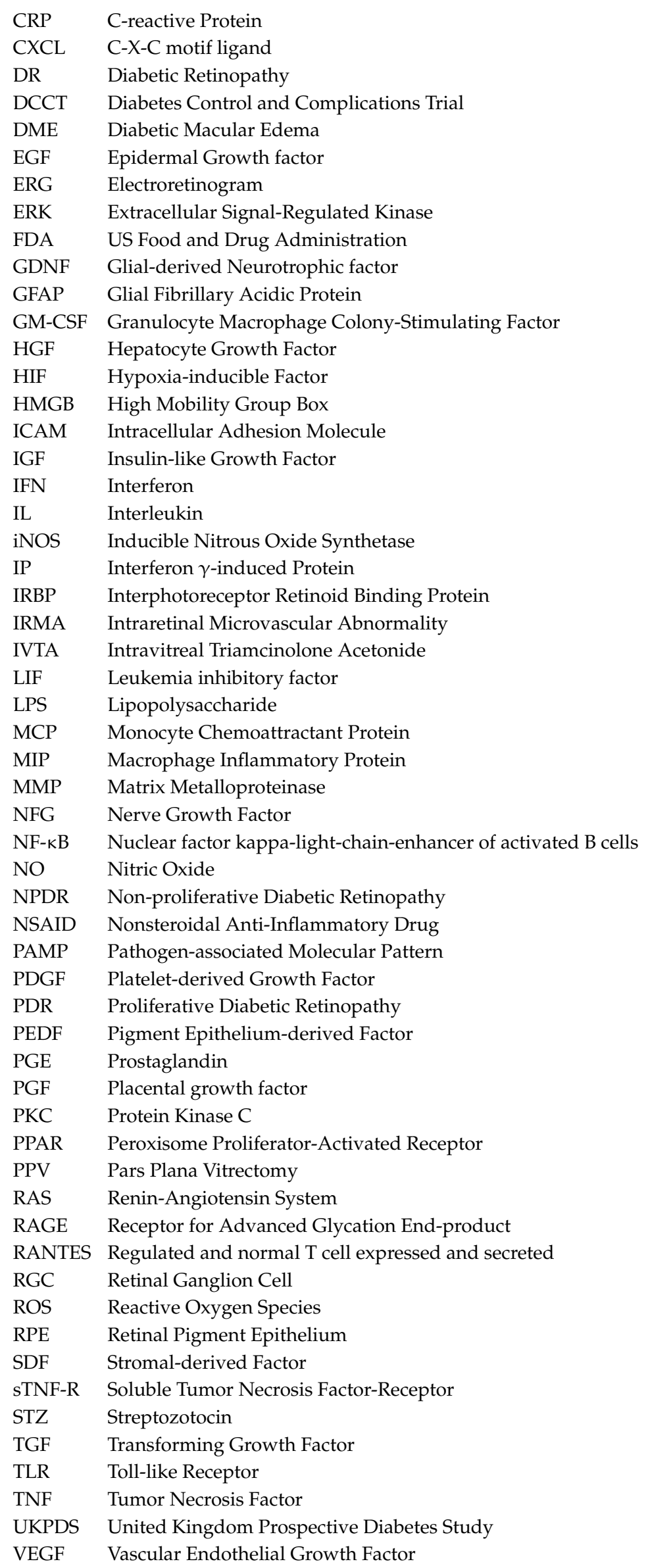




\section{References}

1. Klein, B.E. Overview of epidemiologic studies of diabetic retinopathy. Ophthalmic Epidemiol. 2007, 14, 179-183. [CrossRef] [PubMed]

2. Kempen, J.H.; O'Colmain, B.J.; Leske, M.C.; Haffner, S.M.; Klein, R.; Moss, S.E.; Taylor, H.R.; Hamman, R.F.; Eye Diseases Prevalence Research Group. The prevalence of diabetic retinopathy among adults in the United States. Arch. Ophthalmol. 2004, 122, 552-563. [PubMed]

3. Zhang, X.; Saaddine, J.B.; Chou, C.F.; Cotch, M.F.; Cheng, Y.J.; Geiss, L.S.; Gregg, E.W.; Albright, A.L.; Klein, B.E.; Klein, R. Prevalence of diabetic retinopathy in the United States, 2005-2008. JAMA 2010, 304, 649-656. [CrossRef] [PubMed]

4. AAO PPP Retina/Vitreous Panel, Hoskins Center for Quality Eye Care. Diabetic Retinopathy Ppp_Updated. 2016. Available online: http:/ / www.aao.org/preferred-practice-pattern/diabetic-retinopathy-ppp--2014 (accessed on 30 October 2017).

5. Frey, T.; Antonetti, D.A. Alterations to the blood-retinal barrier in diabetes: Cytokines and reactive oxygen species. Antioxid. Redox Signal 2011, 15, 1271-1284. [CrossRef] [PubMed]

6. Zhang, X.; Zeng, H.; Bao, S.; Wang, N.; Gillies, M.C. Diabetic macular edema: New concepts in patho-physiology and treatment. Cell Biosci. 2014, 4, 27. [CrossRef] [PubMed]

7. Daruich, A.; Matet, A.; Moulin, A.; Kowalczuk, L.; Nicolas, M.; Sellam, A.; Rothschild, P.R.; Omri, S.; Gelize, E.; Jonet, L.; et al. Mechanisms of macular edema: Beyond the surface. Prog. Retin. Eye Res. 2017. [CrossRef] [PubMed]

8. Miller, J.W.; Adamis, A.P.; Shima, D.T.; D'Amore, P.A.; Moulton, R.S.; O’Reilly, M.S.; Folkman, J.; Dvorak, H.F.; Brown, L.F.; Berse, B.; et al. Vascular endothelial growth factor/vascular permeability factor is temporally and spatially correlated with ocular angiogenesis in a primate model. Am. J. Pathol. 1994, 145, 574-584. [CrossRef] [PubMed]

9. Ferrara, N.; Davis-Smyth, T. The biology of vascular endothelial growth factor. Endocr. Rev. 1997, 18, 4-25. [CrossRef] [PubMed]

10. Singer, M.A.; Kermany, D.S.; Waters, J.; Jansen, M.E.; Tyler, L. Diabetic macular edema: It is more than just VEGF. F1000Research 2016, 5. [CrossRef] [PubMed]

11. Gardner, T.W.; Abcouwer, S.F.; Barber, A.J.; Jackson, G.R. An integrated approach to diabetic retinopathy research. Arch. Ophthalmol. 2011, 129, 230-235. [CrossRef] [PubMed]

12. Funatsu, H.; Noma, H.; Mimura, T.; Eguchi, S.; Hori, S. Association of vitreous inflammatory factors with diabetic macular edema. Ophthalmology 2009, 116, 73-79. [CrossRef] [PubMed]

13. Elner, S.G.; Elner, V.M.; Jaffe, G.J.; Stuart, A.; Kunkel, S.L.; Strieter, R.M. Cytokines in proliferative diabetic retinopathy and proliferative vitreoretinopathy. Curr. Eye Res. 1995, 14, 1045-1053. [CrossRef] [PubMed]

14. Mitamura, Y.; Takeuchi, S.; Matsuda, A.; Tagawa, Y.; Mizue, Y.; Nishihira, J. Monocyte chemotactic protein-1 in the vitreous of patients with proliferative diabetic retinopathy. Ophthalmologica 2001, 215, 415-418. [CrossRef] [PubMed]

15. Hernandez, Y.; Arora, S.; Erb-Downward, J.R.; McDonald, R.A.; Toews, G.B.; Huffnagle, G.B. Distinct roles for IL-4 and IL-10 in regulating T2 immunity during allergic bronchopulmonary mycosis. J. Immunol. 2005, 174, 1027-1036. [CrossRef] [PubMed]

16. Abu El-Asrar, A.M.; Struyf, S.; Kangave, D.; Geboes, K.; Van Damme, J. Chemokines in proliferative diabetic retinopathy and proliferative vitreoretinopathy. Eur. Cytokine Netw. 2006, 17, 155-165. [CrossRef] [PubMed]

17. Muramatsu, D.; Wakabayashi, Y.; Usui, Y.; Okunuki, Y.; Kezuka, T.; Goto, H. Correlation of complement fragment C5a with inflammatory cytokines in the vitreous of patients with proliferative diabetic retinopathy. Graefes Arch. Clin. Exp. Ophthalmol. 2013, 251, 15-17. [CrossRef] [PubMed]

18. Wakabayashi, Y.; Usui, Y.; Okunuki, Y.; Kezuka, T.; Takeuchi, M.; Goto, H.; Iwasaki, T. Correlation of vascular endothelial growth factor with chemokines in the vitreous in diabetic retinopathy. Retina 2010, 30, 339-344. [CrossRef] [PubMed]

19. Joussen, A.M.; Murata, T.; Tsujikawa, A.; Kirchhof, B.; Bursell, S.E.; Adamis, A.P. Leukocyte-mediated endothelial cell injury and death in the diabetic retina. Am. J. Pathol. 2001, 158, 147-152. [CrossRef]

20. Powell, E.D.; Field, R.A. Diabetic retinopathy and rheumatoid arthritis. Lancet 1964, 2, 17-18. [CrossRef] 
21. Krady, J.K.; Basu, A.; Allen, C.M.; Xu, Y.; LaNoue, K.F.; Gardner, T.W.; Levison, S.W. Minocycline reduces proinflammatory cytokine expression, microglial activation, and Caspase-3 activation in a rodent model of diabetic retinopathy. Diabetes 2005, 54, 1559-1565. [CrossRef] [PubMed]

22. Lorenzi, M.; Gerhardinger, C. Early cellular and molecular changes induced by diabetes in the retina. Diabetologia 2001, 44, 791-804. [CrossRef] [PubMed]

23. Lieth, E.; Gardner, T.W.; Barber, A.J.; Antonetti, D.A.; Penn State Retina Research, G. Retinal neurodegeneration: Early pathology in diabetes. Clin. Exp. Ophthalmol. 2000, 28, 3-8. [CrossRef] [PubMed]

24. Barber, A.J.; Lieth, E.; Khin, S.A.; Antonetti, D.A.; Buchanan, A.G.; Gardner, T.W. Neural apoptosis in the retina during experimental and human diabetes. Early onset and effect of insulin. J. Clin. Investig. 1998, 102, 783-791. [CrossRef] [PubMed]

25. Kern, T.S.; Barber, A.J. Retinal ganglion cells in diabetes. J. Physiol. 2008, 586, 4401-4408. [CrossRef] [PubMed]

26. Park, S.H.; Park, J.W.; Park, S.J.; Kim, K.Y.; Chung, J.W.; Chun, M.H.; Oh, S.J. Apoptotic death of photoreceptors in the streptozotocin-induced diabetic rat retina. Diabetologia 2003, 46, 1260-1268. [CrossRef] [PubMed]

27. Enzsoly, A.; Szabo, A.; Kantor, O.; David, C.; Szalay, P.; Szabo, K.; Szel, A.; Nemeth, J.; Lukats, A. Pathologic alterations of the outer retina in streptozotocin-induced diabetes. Investig. Ophthalmol. Vis. Sci. 2014, 55, 3686-3699. [CrossRef] [PubMed]

28. Ostroy, S.E.; Frede, S.M.; Wagner, E.F.; Gaitatzes, C.G.; Janle, E.M. Decreased rhodopsin regeneration in diabetic mouse eyes. Investig. Ophthalmol. Vis. Sci. 1994, 35, 3905-3909.

29. Mizutani, M.; Gerhardinger, C.; Lorenzi, M. Muller cell changes in human diabetic retinopathy. Diabetes 1998, 47, 445-449. [CrossRef] [PubMed]

30. Abu-El-Asrar, A.M.; Dralands, L.; Missotten, L.; Al-Jadaan, I.A.; Geboes, K. Expression of apoptosis markers in the retinas of human subjects with diabetes. Investig. Ophthalmol. Vis. Sci. 2004, 45, 2760-2766. [CrossRef] [PubMed]

31. Langmann, T. Microglia activation in retinal degeneration. J. Leukoc. Biol. 2007, 81, 1345-1351. [CrossRef] [PubMed]

32. Verma, A.; Rani, P.K.; Raman, R.; Pal, S.S.; Laxmi, G.; Gupta, M.; Sahu, C.; Vaitheeswaran, K.; Sharma, T. Is neuronal dysfunction an early sign of diabetic retinopathy? Microperimetry and spectral domain optical coherence tomography (Sd-Oct) study in individuals with diabetes, but no diabetic retinopathy. Eye (London) 2009, 23, 1824-1830. [CrossRef] [PubMed]

33. Van der Torren, K.; van Lith, G. Oscillatory potentials in early diabetic retinopathy. Doc. Ophthalmol. 1989, 71, 375-379. [CrossRef] [PubMed]

34. Sokol, S.; Moskowitz, A.; Skarf, B.; Evans, R.; Molitch, M.; Senior, B. Contrast sensitivity in diabetics with and without background retinopathy. Arch. Ophthalmol. 1985, 103, 51-54. [CrossRef] [PubMed]

35. Roy, M.S.; Gunkel, R.D.; Podgor, M.J. Color vision defects in early diabetic retinopathy. Arch. Ophthalmol. 1986, 104, 225-228. [CrossRef] [PubMed]

36. Sun, J.K.; Lin, M.M.; Lammer, J.; Prager, S.; Sarangi, R.; Silva, P.S.; Aiello, L.P. Disorganization of the retinal inner layers as a predictor of visual acuity in eyes with center-involved diabetic macular edema. JAMA Ophthalmol. 2014, 132, 1309-1316. [CrossRef] [PubMed]

37. Bonnin, S.; Tadayoni, R.; Erginay, A.; Massin, P.; Dupas, B. Correlation between ganglion cell layer thinning and poor visual function after resolution of diabetic macular edema. Investig. Ophthalmol. Vis. Sci. 2015, 56, 978-982. [CrossRef] [PubMed]

38. Shin, H.J.; Lee, S.H.; Chung, H.; Kim, H.C. Association between photoreceptor integrity and visual outcome in diabetic macular edema. Graefes Arch. Clin. Exp. Ophthalmol. 2012, 250, 61-70. [CrossRef] [PubMed]

39. Agemy, S.A.; Scripsema, N.K.; Shah, C.M.; Chui, T.; Garcia, P.M.; Lee, J.G.; Gentile, R.C.; Hsiao, Y.S.; Zhou, Q.; Ko, T.; et al. Retinal vascular perfusion density mapping using optical coherence tomography angiography in normals and diabetic retinopathy patients. Retina 2015, 35, 2353-2363. [CrossRef] [PubMed]

40. Antonetti, D.A.; Klein, R.; Gardner, T.W. Diabetic retinopathy. N. Engl. J. Med. 2012, 366, 1227-1239. [CrossRef] [PubMed]

41. Jialal, I.; Kaur, H. The role of toll-like receptors in diabetes-induced inflammation: Implications for vascular complications. Curr. Diabetes Rep. 2012, 12, 172-179. [CrossRef] [PubMed] 
42. Serhan, C.N.; Brain, S.D.; Buckley, C.D.; Gilroy, D.W.; Haslett, C.; O’Neill, L.A.; Perretti, M.; Rossi, A.G.; Wallace, J.L. Resolution of inflammation: State of the art, definitions and terms. FASEB J. 2007, 21, 325-332. [CrossRef] [PubMed]

43. Hotamisligil, G.S. Inflammation and metabolic disorders. Nature 2006, 444, 860-867. [CrossRef] [PubMed]

44. Adamis, A.P. Is diabetic retinopathy an inflammatory disease? Br. J. Ophthalmol. 2002, 86, 363-365. [CrossRef] [PubMed]

45. Kern, T.S. Contributions of inflammatory processes to the development of the early stages of diabetic retinopathy. Exp. Diabetes Res. 2007, 2007, 95103. [CrossRef] [PubMed]

46. Noda, K.; Nakao, S.; Ishida, S.; Ishibashi, T. Leukocyte adhesion molecules in diabetic retinopathy. J. Ophthalmol. 2012, 2012, 279037. [CrossRef] [PubMed]

47. Vujosevic, S.; Micera, A.; Bini, S.; Berton, M.; Esposito, G.; Midena, E. Aqueous humor biomarkers of muller cell activation in diabetic eyes. Investig. Ophthalmol. Vis. Sci. 2015, 56, 3913-3918. [CrossRef] [PubMed]

48. Khalfaoui, T.; Lizard, G.; Ouertani-Meddeb, A. Adhesion molecules (ICAM-1 and VCAM-1) and diabetic retinopathy in type 2 diabetes. J. Mol. Histol. 2008, 39, 243-249. [CrossRef] [PubMed]

49. Vujosevic, S.; Micera, A.; Bini, S.; Berton, M.; Esposito, G.; Midena, E. Proteome analysis of retinal glia cells-related inflammatory cytokines in the aqueous humour of diabetic patients. Acta Ophthalmol. 2016, 94, 56-64. [CrossRef] [PubMed]

50. Sun, W.; Gerhardinger, C.; Dagher, Z.; Hoehn, T.; Lorenzi, M. Aspirin at low-intermediate concentrations protects retinal vessels in experimental diabetic retinopathy through non-platelet-mediated effects. Diabetes 2005, 54, 3418-3426. [CrossRef] [PubMed]

51. Boss, J.D.; Singh, P.K.; Pandya, H.K.; Tosi, J.; Kim, C.; Tewari, A.; Juzych, M.S.; Abrams, G.W.; Kumar, A. Assessment of neurotrophins and inflammatory mediators in vitreous of patients with diabetic retinopathy. Investig. Ophthalmol. Vis. Sci. 2017, 58, 5594-5603. [CrossRef] [PubMed]

52. Wu, H.; Hwang, D.K.; Song, X.; Tao, Y. Association between aqueous cytokines and diabetic retinopathy stage. J. Ophthalmol. 2017, 2017, 9402198. [CrossRef] [PubMed]

53. Demircan, N.; Safran, B.G.; Soylu, M.; Ozcan, A.A.; Sizmaz, S. Determination of vitreous interleukin-1 (IL-1) and tumour necrosis factor (TNF) levels in proliferative diabetic retinopathy. Eye (London) 2006, 20, 1366-1369. [CrossRef] [PubMed]

54. Yoshida, S.; Yoshida, A.; Ishibashi, T.; Elner, S.G.; Elner, V.M. Role of MCP-1 and MIP-1alpha in retinal neovascularization during postischemic inflammation in a mouse model of retinal neovascularization. J. Leukoc. Biol. 2003, 73, 137-144. [CrossRef] [PubMed]

55. Rusnak, S.; Vrzalova, J.; Sobotova, M.; Hecova, L.; Ricarova, R.; Topolcan, O. The measurement of intraocular biomarkers in various stages of proliferative diabetic retinopathy using multiplex xmap technology. J. Ophthalmol. 2015, 2015, 424783. [CrossRef] [PubMed]

56. Doganay, S.; Evereklioglu, C.; Er, H.; Turkoz, Y.; Sevinc, A.; Mehmet, N.; Savli, H. Comparison of serum no, TNF-alpha, IL-1beta, SIL-2r, IL-6 and il-8 levels with grades of retinopathy in patients with diabetes mellitus. Eye (London) 2002, 16, 163-170. [CrossRef] [PubMed]

57. Giebel, S.J.; Menicucci, G.; McGuire, P.G.; Das, A. Matrix metalloproteinases in early diabetic retinopathy and their role in alteration of the blood-retinal barrier. Lab. Investig. 2005, 85, 597-607. [CrossRef] [PubMed]

58. Patel, J.I.; Hykin, P.G.; Gregor, Z.J.; Boulton, M.; Cree, I.A. Angiopoietin concentrations in diabetic retinopathy. Br. J. Ophthalmol. 2005, 89, 480-483. [CrossRef] [PubMed]

59. Chalam, K.V.; Grover, S.; Sambhav, K.; Balaiya, S.; Murthy, R.K. Aqueous interleukin-6 levels are superior to vascular endothelial growth factor in predicting therapeutic response to bevacizumab in age-related macular degeneration. J. Ophthalmol. 2014, 2014, 502174. [CrossRef] [PubMed]

60. Joussen, A.M.; Poulaki, V.; Qin, W.; Kirchhof, B.; Mitsiades, N.; Wiegand, S.J.; Rudge, J.; Yancopoulos, G.D.; Adamis, A.P. Retinal vascular endothelial growth factor induces intercellular adhesion molecule-1 and endothelial nitric oxide synthase expression and initiates early diabetic retinal leukocyte adhesion in vivo. Am. J. Pathol. 2002, 160, 501-509. [CrossRef]

61. Rungger-Brandle, E.; Dosso, A.A.; Leuenberger, P.M. Glial reactivity, an early feature of diabetic retinopathy. Investig. Ophthalmol. Vis. Sci. 2000, 41, 1971-1980.

62. Cusick, M.; Chew, E.Y.; Chan, C.C.; Kruth, H.S.; Murphy, R.P.; Ferris, F.L., 3rd. Histopathology and regression of retinal hard exudates in diabetic retinopathy after reduction of elevated serum lipid levels. Ophthalmology 2003, 110, 2126-2133. [CrossRef] [PubMed] 
63. Zhang, J.; Gerhardinger, C.; Lorenzi, M. Early complement activation and decreased levels of glycosylphosphatidylinositol-anchored complement inhibitors in human and experimental diabetic retinopathy. Diabetes 2002, 51, 3499-3504. [CrossRef] [PubMed]

64. Antonetti, D.A.; Barber, A.J.; Bronson, S.K.; Freeman, W.M.; Gardner, T.W.; Jefferson, L.S.; Kester, M.; Kimball, S.R.; Krady, J.K.; LaNoue, K.F.; et al. Diabetic retinopathy: Seeing beyond glucose-induced microvascular disease. Diabetes 2006, 55, 2401-2411. [CrossRef] [PubMed]

65. Cardona, S.M.; Mendiola, A.S.; Yang, Y.C.; Adkins, S.L.; Torres, V.; Cardona, A.E. Disruption of fractalkine signaling leads to microglial activation and neuronal damage in the diabetic retina. ASN Neuro 2015, 7. [CrossRef] [PubMed]

66. Vallejo, S.; Palacios, E.; Romacho, T.; Villalobos, L.; Peiro, C.; Sanchez-Ferrer, C.F. The interleukin-1 receptor antagonist anakinra improves endothelial dysfunction in streptozotocin-induced diabetic rats. Cardiovasc. Diabetol. 2014, 13, 158. [CrossRef] [PubMed]

67. Li, Q.; Verma, A.; Han, P.Y.; Nakagawa, T.; Johnson, R.J.; Grant, M.B.; Campbell-Thompson, M.; Jarajapu, Y.P.; Lei, B.; Hauswirth, W.W. Diabetic enos-knockout mice develop accelerated retinopathy. Investig. Ophthalmol. Vis. Sci. 2010, 51, 5240-5246. [CrossRef] [PubMed]

68. Funatsu, H.; Yamashita, H.; Sakata, K.; Noma, H.; Mimura, T.; Suzuki, M.; Eguchi, S.; Hori, S. Vitreous levels of vascular endothelial growth factor and intercellular adhesion molecule 1 are related to diabetic macular edema. Ophthalmology 2005, 112, 806-816. [CrossRef] [PubMed]

69. Bromberg-White, J.L.; Glazer, L.; Downer, R.; Furge, K.; Boguslawski, E.; Duesbery, N.S. Identification of VEGF-independent cytokines in proliferative diabetic retinopathy vitreous. Investig. Ophthalmol. Vis. Sci. 2013, 54, 6472-6480. [CrossRef] [PubMed]

70. Adamiec-Mroczek, J.; Oficjalska-Mlynczak, J.; Misiuk-Hojlo, M. Proliferative diabetic retinopathy-the influence of diabetes control on the activation of the intraocular molecule system. Diabetes Res. Clin. Pract. 2009, 84, 46-50. [CrossRef] [PubMed]

71. Jain, A.; Saxena, S.; Khanna, V.K.; Shukla, R.K.; Meyer, C.H. Status of serum VEGF and ICAM-1 and its association with external limiting membrane and inner segment-outer segment junction disruption in type 2 diabetes mellitus. Mol. Vis. 2013, 19, 1760-1768. [PubMed]

72. Burgos, R.; Simo, R.; Audi, L.; Mateo, C.; Mesa, J.; Garcia-Ramirez, M.; Carrascosa, A. Vitreous levels of vascular endothelial growth factor are not influenced by its serum concentrations in diabetic retinopathy. Diabetologia 1997, 40, 1107-1109. [CrossRef] [PubMed]

73. Hang, H.; Yuan, S.; Yang, Q.; Yuan, D.; Liu, Q. Multiplex bead array assay of plasma cytokines in type 2 diabetes mellitus with diabetic retinopathy. Mol. Vis. 2014, 20, 1137-1145. [PubMed]

74. Jonas, J.B.; Jonas, R.A.; Neumaier, M.; Findeisen, P. Cytokine concentration in aqueous humor of eyes with diabetic macular edema. Retina 2012, 32, 2150-2157. [CrossRef] [PubMed]

75. Ghodasra, D.H.; Fante, R.; Gardner, T.W.; Langue, M.; Niziol, L.M.; Besirli, C.; Cohen, S.R.; Dedania, V.S.; Demirci, H.; Jain, N.; et al. Safety and feasibility of quantitative multiplexed cytokine analysis from office-based vitreous aspiration. Investig. Ophthalmol. Vis. Sci. 2016, 57, 3017-3023. [CrossRef] [PubMed]

76. Mao, C.; Yan, H. Roles of elevated intravitreal IL-1beta and IL-10 levels in proliferative diabetic retinopathy. Indian J. Ophthalmol. 2014, 62, 699-701. [PubMed]

77. Kim, M.; Kim, Y.; Lee, S.J. Comparison of aqueous concentrations of angiogenic and inflammatory cytokines based on optical coherence tomography patterns of diabetic macular edema. Indian J. Ophthalmol. 2015, 63, 312-317. [CrossRef] [PubMed]

78. Lee, W.J.; Kang, M.H.; Seong, M.; Cho, H.Y. Comparison of aqueous concentrations of angiogenic and inflammatory cytokines in diabetic macular oedema and macular oedema due to branch retinal vein occlusion. Br. J. Ophthalmol. 2012, 96, 1426-1430. [CrossRef] [PubMed]

79. Tang, S.; Le-Ruppert, K.C. Activated t lymphocytes in epiretinal membranes from eyes of patients with proliferative diabetic retinopathy. Graefes Arch. Clin. Exp. Ophthalmol. 1995, 233, 21-25. [CrossRef] [PubMed]

80. Takeuchi, M.; Sato, T.; Tanaka, A.; Muraoka, T.; Taguchi, M.; Sakurai, Y.; Karasawa, Y.; Ito, M. Elevated levels of cytokines associated with $\mathrm{TH} 2$ and TH17 cells in vitreous fluid of proliferative diabetic retinopathy patients. PLoS ONE 2015, 10, e0137358. [CrossRef] [PubMed]

81. Meleth, A.D.; Agron, E.; Chan, C.C.; Reed, G.F.; Arora, K.; Byrnes, G.; Csaky, K.G.; Ferris, F.L., 3rd; Chew, E.Y. Serum inflammatory markers in diabetic retinopathy. Investig. Ophthalmol. Vis. Sci. 2005, 46, 4295-4301. [CrossRef] [PubMed] 
82. Noma, H.; Mimura, T.; Yasuda, K.; Motohashi, R.; Kotake, O.; Shimura, M. Aqueous humor levels of soluble vascular endothelial growth factor receptor and inflammatory factors in diabetic macular edema. Ophthalmologica 2017, 238, 81-88. [CrossRef] [PubMed]

83. Ogata, N.; Nishikawa, M.; Nishimura, T.; Mitsuma, Y.; Matsumura, M. Unbalanced vitreous levels of pigment epithelium-derived factor and vascular endothelial growth factor in diabetic retinopathy. Am. J. Ophthalmol. 2002, 134, 348-353. [CrossRef]

84. Duh, E.J.; Yang, H.S.; Haller, J.A.; De Juan, E.; Humayun, M.S.; Gehlbach, P.; Melia, M.; Pieramici, D.; Harlan, J.B.; Campochiaro, P.A.; et al. Vitreous levels of pigment epithelium-derived factor and vascular endothelial growth factor: Implications for ocular angiogenesis. Am. J. Ophthalmol. 2004, 137, 668-674. [PubMed]

85. Wang, S.; Gottlieb, J.L.; Sorenson, C.M.; Sheibani, N. Modulation of thrombospondin 1 and pigment epithelium-derived factor levels in vitreous fluid of patients with diabetes. Arch. Ophthalmol. 2009, 127, 507-513. [CrossRef] [PubMed]

86. Funatsu, H.; Yamashita, H.; Nakamura, S.; Mimura, T.; Eguchi, S.; Noma, H.; Hori, S. Vitreous levels of pigment epithelium-derived factor and vascular endothelial growth factor are related to diabetic macular edema. Ophthalmology 2006, 113, 294-301. [CrossRef] [PubMed]

87. Meyer-Schwickerath, R.; Pfeiffer, A.; Blum, W.F.; Freyberger, H.; Klein, M.; Losche, C.; Rollmann, R.; Schatz, H. Vitreous levels of the insulin-like growth factors I and II, and the insulin-like growth factor binding proteins 2 and 3, increase in neovascular eye disease. Studies in nondiabetic and diabetic subjects. J. Clin. Investig. 1993, 92, 2620-2625. [CrossRef] [PubMed]

88. Grant, M.; Russell, B.; Fitzgerald, C.; Merimee, T.J. Insulin-like growth factors in vitreous. Studies in control and diabetic subjects with neovascularization. Diabetes 1986, 35, 416-420. [CrossRef] [PubMed]

89. Sivalingam, A.; Kenney, J.; Brown, G.C.; Benson, W.E.; Donoso, L. Basic fibroblast growth factor levels in the vitreous of patients with proliferative diabetic retinopathy. Arch. Ophthalmol. 1990, 108, 869-872. [CrossRef] [PubMed]

90. Al Kahtani, E.; Xu, Z.; Al Rashaed, S.; Wu, L.; Mahale, A.; Tian, J.; Abboud, E.B.; Ghazi, N.G.; Kozak, I.; Gupta, V.; et al. Vitreous levels of placental growth factor correlate with activity of proliferative diabetic retinopathy and are not influenced by bevacizumab treatment. Eye (London) 2017, 31, 529-536. [CrossRef] [PubMed]

91. Cassidy, L.; Barry, P.; Shaw, C.; Duffy, J.; Kennedy, S. Platelet derived growth factor and fibroblast growth factor basic levels in the vitreous of patients with vitreoretinal disorders. Br. J. Ophthalmol. 1998, 82, 181-185. [CrossRef] [PubMed]

92. Yngen, M.; Ostenson, C.G.; Hu, H.; Li, N.; Hjemdahl, P.; Wallen, N.H. Enhanced p-selectin expression and increased soluble cd40 ligand in patients with type 1 diabetes mellitus and microangiopathy: Evidence for platelet hyperactivity and chronic inflammation. Diabetologia 2004, 47, 537-540. [CrossRef] [PubMed]

93. Loukovaara, S.; Koivunen, P.; Ingles, M.; Escobar, J.; Vento, M.; Andersson, S. Elevated protein carbonyl and HIF-1alpha levels in eyes with proliferative diabetic retinopathy. Acta Ophthalmol. 2014, 92, 323-327. [CrossRef] [PubMed]

94. Wang, X.; Wang, G.; Wang, Y. Intravitreous vascular endothelial growth factor and hypoxia-inducible factor 1A in patients with proliferative diabetic retinopathy. Am. J. Ophthalmol. 2009, 148, 883-889. [CrossRef] [PubMed]

95. Tang, J.; Kern, T.S. Inflammation in diabetic retinopathy. Prog. Retin. Eye Res. 2011, 30, 343-358. [CrossRef] [PubMed]

96. Rangasamy, S.; McGuire, P.G.; Das, A. Diabetic retinopathy and inflammation: Novel therapeutic targets. Middle East Afr. J. Ophthalmol. 2012, 19, 52-59. [PubMed]

97. Aplin, A.C.; Gelati, M.; Fogel, E.; Carnevale, E.; Nicosia, R.F. Angiopoietin-1 and vascular endothelial growth factor induce expression of inflammatory cytokines before angiogenesis. Physiol. Genom. 2006, 27, $20-28$. [CrossRef] [PubMed]

98. Voronov, E.; Shouval, D.S.; Krelin, Y.; Cagnano, E.; Benharroch, D.; Iwakura, Y.; Dinarello, C.A.; Apte, R.N. IL-1 is required for tumor invasiveness and angiogenesis. Proc. Natl. Acad. Sci. USA 2003, 100, 2645-2650. [CrossRef] [PubMed] 
99. Leali, D.; Dell'Era, P.; Stabile, H.; Sennino, B.; Chambers, A.F.; Naldini, A.; Sozzani, S.; Nico, B.; Ribatti, D.; Presta, M. Osteopontin (ETA-1) and fibroblast growth factor-2 cross-talk in angiogenesis. J. Immunol. 2003, 171, 1085-1093. [CrossRef] [PubMed]

100. Busik, J.V.; Mohr, S.; Grant, M.B. Hyperglycemia-induced reactive oxygen species toxicity to endothelial cells is dependent on paracrine mediators. Diabetes 2008, 57, 1952-1965. [CrossRef] [PubMed]

101. Chen, W.; Esselman, W.J.; Jump, D.B.; Busik, J.V. Anti-inflammatory effect of docosahexaenoic acid on cytokine-induced adhesion molecule expression in human retinal vascular endothelial cells. Investig. Ophthalmol. Vis. Sci. 2005, 46, 4342-4347. [CrossRef] [PubMed]

102. Joussen, A.M.; Poulaki, V.; Le, M.L.; Koizumi, K.; Esser, C.; Janicki, H.; Schraermeyer, U.; Kociok, N.; Fauser, S.; Kirchhof, B.; et al. A central role for inflammation in the pathogenesis of diabetic retinopathy. FASEB J. 2004, 18, 1450-1452. [CrossRef] [PubMed]

103. Miyamoto, K.; Khosrof, S.; Bursell, S.E.; Rohan, R.; Murata, T.; Clermont, A.C.; Aiello, L.P.; Ogura, Y.; Adamis, A.P. Prevention of leukostasis and vascular leakage in streptozotocin-induced diabetic retinopathy via intercellular adhesion molecule-1 inhibition. Proc. Natl. Acad. Sci. USA 1999, 96, 10836-10841. [CrossRef] [PubMed]

104. Stitt, A.W.; Curtis, T.M.; Chen, M.; Medina, R.J.; McKay, G.J.; Jenkins, A.; Gardiner, T.A.; Lyons, T.J.; Hammes, H.P.; Simo, R.; et al. The progress in understanding and treatment of diabetic retinopathy. Prog. Retin. Eye Res. 2016, 51, 156-186. [CrossRef] [PubMed]

105. Durham, J.T.; Herman, I.M. Microvascular modifications in diabetic retinopathy. Curr. Diabetes Rep. 2011, 11, 253-264. [CrossRef] [PubMed]

106. Valle, A.; Giamporcaro, G.M.; Scavini, M.; Stabilini, A.; Grogan, P.; Bianconi, E.; Sebastiani, G.; Masini, M.; Maugeri, N.; Porretti, L.; et al. Reduction of circulating neutrophils precedes and accompanies type 1 diabetes. Diabetes 2013, 62, 2072-2077. [CrossRef] [PubMed]

107. Engerman, R.L. Pathogenesis of diabetic retinopathy. Diabetes 1989, 38, 1203-1206. [CrossRef] [PubMed]

108. Dell'omo, R.; Semeraro, F.; Bamonte, G.; Cifariello, F.; Romano, M.R.; Costagliola, C. Vitreous mediators in retinal hypoxic diseases. Mediat. Inflamm. 2013, 2013, 935301. [CrossRef] [PubMed]

109. Costagliola, C.; Romano, V.; De Tollis, M.; Aceto, F.; dell'Omo, R.; Romano, M.R.; Pedicino, C.; Semeraro, F. TNF-alpha levels in tears: A novel biomarker to assess the degree of diabetic retinopathy. Mediat. Inflamm. 2013, 2013, 629529. [CrossRef] [PubMed]

110. Yoshida, S.; Yoshida, A.; Ishibashi, T. Induction of IL-8, MCP-1, and BFGF by TNF-alpha in retinal glial cells: Implications for retinal neovascularization during post-ischemic inflammation. Graefes Arch. Clin. Exp. Ophthalmol. 2004, 242, 409-413. [CrossRef] [PubMed]

111. Tsutsumi, C.; Sonoda, K.H.; Egashira, K.; Qiao, H.; Hisatomi, T.; Nakao, S.; Ishibashi, M.; Charo, I.F.; Sakamoto, T.; Murata, T.; et al. The critical role of ocular-infiltrating macrophages in the development of choroidal neovascularization. J. Leukoc. Biol. 2003, 74, 25-32. [CrossRef] [PubMed]

112. Sakurai, E.; Taguchi, H.; Anand, A.; Ambati, B.K.; Gragoudas, E.S.; Miller, J.W.; Adamis, A.P.; Ambati, J. Targeted disruption of the CD18 or ICAM-1 gene inhibits choroidal neovascularization. Investig. Ophthalmol. Vis. Sci. 2003, 44, 2743-2749. [CrossRef]

113. Sennlaub, F.; Valamanesh, F.; Vazquez-Tello, A.; El-Asrar, A.M.; Checchin, D.; Brault, S.; Gobeil, F.; Beauchamp, M.H.; Mwaikambo, B.; Courtois, Y.; et al. Cyclooxygenase-2 in human and experimental ischemic proliferative retinopathy. Circulation 2003, 108, 198-204. [CrossRef] [PubMed]

114. Ayalasomayajula, S.P.; Kompella, U.B. Celecoxib, a selective cyclooxygenase-2 inhibitor, inhibits retinal vascular endothelial growth factor expression and vascular leakage in a streptozotocin-induced diabetic rat model. Eur. J. Pharmacol. 2003, 458, 283-289. [CrossRef]

115. Abu El-Asrar, A.M.; Mohammad, G.; Nawaz, M.I.; Siddiquei, M.M. High-mobility group box-1 modulates the expression of inflammatory and angiogenic signaling pathways in diabetic retina. Curr. Eye Res. 2015, 40, 1141-1152. [CrossRef] [PubMed]

116. Fiuza, C.; Bustin, M.; Talwar, S.; Tropea, M.; Gerstenberger, E.; Shelhamer, J.H.; Suffredini, A.F. Inflammation-promoting activity of HMGB1 on human microvascular endothelial cells. Blood 2003, 101, 2652-2660. [CrossRef] [PubMed]

117. Treutiger, C.J.; Mullins, G.E.; Johansson, A.S.; Rouhiainen, A.; Rauvala, H.M.; Erlandsson-Harris, H.; Andersson, U.; Yang, H.; Tracey, K.J.; Andersson, J.; et al. High mobility group 1 b-box mediates activation of human endothelium. J. Intern. Med. 2003, 254, 375-385. [CrossRef] [PubMed] 
118. Croll, S.D.; Ransohoff, R.M.; Cai, N.; Zhang, Q.; Martin, F.J.; Wei, T.; Kasselman, L.J.; Kintner, J.; Murphy, A.J.; Yancopoulos, G.D.; et al. VEGF-mediated inflammation precedes angiogenesis in adult brain. Exp. Neurol. 2004, 187, 388-402. [CrossRef] [PubMed]

119. Marumo, T.; Schini-Kerth, V.B.; Busse, R. Vascular endothelial growth factor activates nuclear factor-kappab and induces monocyte chemoattractant protein-1 in bovine retinal endothelial cells. Diabetes 1999, 48, 1131-1137. [CrossRef] [PubMed]

120. Lee, T.H.; Avraham, H.; Lee, S.H.; Avraham, S. Vascular endothelial growth factor modulates neutrophil transendothelial migration via up-regulation of interleukin-8 in human brain microvascular endothelial cells. J. Biol. Chem. 2002, 277, 10445-10451. [CrossRef] [PubMed]

121. Cai, M.; Zhang, X.; Li, Y.; Xu, H. Toll-like receptor 3 activation drives the inflammatory response in oxygen-induced retinopathy in rats. Br. J. Ophthalmol. 2015, 99, 125-132. [CrossRef] [PubMed]

122. Lange, C.; Storkebaum, E.; de Almodovar, C.R.; Dewerchin, M.; Carmeliet, P. Vascular endothelial growth factor: A neurovascular target in neurological diseases. Nat. Rev. Neurol. 2016, 12, 439-454. [CrossRef] [PubMed]

123. Imai, H.; Singh, R.S.; Fort, P.E.; Gardner, T.W. Neuroprotection for diabetic retinopathy. Dev. Ophthalmol. 2009, 44, 56-68. [PubMed]

124. Gilbert, R.E.; Vranes, D.; Berka, J.L.; Kelly, D.J.; Cox, A.; Wu, L.L.; Stacker, S.A.; Cooper, M.E. Vascular endothelial growth factor and its receptors in control and diabetic rat eyes. Lab. Investig. 1998, 78, 1017-1027. [PubMed]

125. Barber, A.J.; Nakamura, M.; Wolpert, E.B.; Reiter, C.E.; Seigel, G.M.; Antonetti, D.A.; Gardner, T.W. Insulin rescues retinal neurons from apoptosis by a phosphatidylinositol 3-kinase/Akt-mediated mechanism that reduces the activation of caspase-3. J. Biol. Chem. 2001, 276, 32814-32821. [CrossRef] [PubMed]

126. Gordon, W.C.; Bazan, N.G. Mediator lipidomics in ophthalmology: Targets for modulation in inflammation, neuroprotection and nerve regeneration. Curr. Eye Res. 2013, 38, 995-1005. [CrossRef] [PubMed]

127. Seki, M.; Tanaka, T.; Nawa, H.; Usui, T.; Fukuchi, T.; Ikeda, K.; Abe, H.; Takei, N. Involvement of brain-derived neurotrophic factor in early retinal neuropathy of streptozotocin-induced diabetes in rats: Therapeutic potential of brain-derived neurotrophic factor for dopaminergic amacrine cells. Diabetes 2004, 53, 2412-2419. [CrossRef] [PubMed]

128. Wang, L.; Deng, Q.Q.; Wu, X.H.; Yu, J.; Yang, X.L.; Zhong, Y.M. Upregulation of glutamate-aspartate transporter by glial cell line-derived neurotrophic factor ameliorates cell apoptosis in neural retina in streptozotocin-induced diabetic rats. CNS Neurosci. Ther. 2013, 19, 945-953. [CrossRef] [PubMed]

129. Aizu, Y.; Katayama, H.; Takahama, S.; Hu, J.; Nakagawa, H.; Oyanagi, K. Topical instillation of ciliary neurotrophic factor inhibits retinal degeneration in streptozotocin-induced diabetic rats. Neuroreport 2003, 14, 2067-2071. [CrossRef] [PubMed]

130. Ali, T.K.; Al-Gayyar, M.M.; Matragoon, S.; Pillai, B.A.; Abdelsaid, M.A.; Nussbaum, J.J.; El-Remessy, A.B. Diabetes-induced peroxynitrite impairs the balance of pro-nerve growth factor and nerve growth factor, and causes neurovascular injury. Diabetologia 2011, 54, 657-668. [CrossRef] [PubMed]

131. Costa, G.N.; Vindeirinho, J.; Cavadas, C.; Ambrosio, A.F.; Santos, P.F. Contribution of tnf receptor 1 to retinal neural cell death induced by elevated glucose. Mol. Cell. Neurosci. 2012, 50, 113-123. [CrossRef] [PubMed]

132. Zong, H.; Ward, M.; Madden, A.; Yong, P.H.; Limb, G.A.; Curtis, T.M.; Stitt, A.W. Hyperglycaemia-induced pro-inflammatory responses by retinal muller glia are regulated by the receptor for advanced glycation end-products (RAGE). Diabetologia 2010, 53, 2656-2666. [CrossRef] [PubMed]

133. Esposito, K.; Nappo, F.; Marfella, R.; Giugliano, G.; Giugliano, F.; Ciotola, M.; Quagliaro, L.; Ceriello, A.; Giugliano, D. Inflammatory cytokine concentrations are acutely increased by hyperglycemia in humans: Role of oxidative stress. Circulation 2002, 106, 2067-2072. [CrossRef] [PubMed]

134. Zheng, L.; Howell, S.J.; Hatala, D.A.; Huang, K.; Kern, T.S. Salicylate-based anti-inflammatory drugs inhibit the early lesion of diabetic retinopathy. Diabetes 2007, 56, 337-345. [CrossRef] [PubMed]

135. Kern, T.S.; Berkowitz, B.A. Photoreceptors in diabetic retinopathy. J. Diabetes Investig. 2015, 6, 371-380. [CrossRef] [PubMed]

136. Du, Y.; Veenstra, A.; Palczewski, K.; Kern, T.S. Photoreceptor cells are major contributors to diabetes-induced oxidative stress and local inflammation in the retina. Proc. Natl. Acad. Sci. USA 2013, 110, 16586-16591. [CrossRef] [PubMed] 
137. Tonade, D.; Liu, H.; Kern, T.S. Photoreceptor cells produce inflammatory mediators that contribute to endothelial cell death in diabetes. Investig. Ophthalmol. Vis. Sci. 2016, 57, 4264-4271. [CrossRef] [PubMed]

138. Yang, L.P.; Sun, H.L.; Wu, L.M.; Guo, X.J.; Dou, H.L.; Tso, M.O.; Zhao, L.; Li, S.M. Baicalein reduces inflammatory process in a rodent model of diabetic retinopathy. Investig. Ophthalmol. Vis. Sci. 2009, 50, 2319-2327. [CrossRef] [PubMed]

139. Scott, I.U.; Jackson, G.R.; Quillen, D.A.; Larsen, M.; Klein, R.; Liao, J.; Holfort, S.; Munch, I.C.; Gardner, T.W. Effect of doxycycline vs placebo on retinal function and diabetic retinopathy progression in patients with severe nonproliferative or non-high-risk proliferative diabetic retinopathy: A randomized clinical trial. JAMA Ophthalmol. 2014, 132, 535-543. [CrossRef] [PubMed]

140. Peters, A.L.; Stunz, L.L.; Bishop, G.A. Cd40 and autoimmunity: The dark side of a great activator. Semin. Immunol. 2009, 21, 293-300. [CrossRef] [PubMed]

141. van Kooten, C.; Banchereau, J. CD40-CD40 ligand. J. Leukoc. Biol. 2000, 67, 2-17. [CrossRef] [PubMed]

142. Portillo, J.C.; Lopez Corcino, Y.; Miao, Y.; Tang, J.; Sheibani, N.; Kern, T.S.; Dubyak, G.R.; Subauste, C.S. CD40 in retinal muller cells induces P2X7-dependent cytokine expression in macrophages/microglia in diabetic mice and development of early experimental diabetic retinopathy. Diabetes 2017, 66, 483-493. [CrossRef] [PubMed]

143. Samuels, I.S.; Portillo, J.C.; Miao, Y.; Kern, T.S.; Subauste, C.S. Loss of CD40 attenuates experimental diabetes-induced retinal inflammation but does not protect mice from electroretinogram defects. Vis. Neurosci. 2017, 34. [CrossRef] [PubMed]

144. Zheng, L.; Du, Y.; Miller, C.; Gubitosi-Klug, R.A.; Kern, T.S.; Ball, S.; Berkowitz, B.A. Critical role of inducible nitric oxide synthase in degeneration of retinal capillaries in mice with streptozotocin-induced diabetes. Diabetologia 2007, 50, 1987-1996. [CrossRef] [PubMed]

145. Li, G.; Tang, J.; Du, Y.; Lee, C.A.; Kern, T.S. Beneficial effects of a novel rage inhibitor on early diabetic retinopathy and tactile allodynia. Mol. Vis. 2011, 17, 3156-3165. [PubMed]

146. Lee, C.A.; Li, G.; Patel, M.D.; Petrash, J.M.; Benetz, B.A.; Veenstra, A.; Amengual, J.; von Lintig, J.; Burant, C.J.; Tang, J.; et al. Diabetes-induced impairment in visual function in mice: Contributions of p38 mapk, rage, leukocytes, and aldose reductase. Investig. Ophthalmol. Vis. Sci. 2014, 55, 2904-2910. [CrossRef] [PubMed]

147. Calderon, G.D.; Juarez, O.H.; Hernandez, G.E.; Punzo, S.M.; De la Cruz, Z.D. Oxidative stress and diabetic retinopathy: Development and treatment. Eye (London) 2017, 31, 1122-1130. [CrossRef] [PubMed]

148. Sorrentino, F.S.; Allkabes, M.; Salsini, G.; Bonifazzi, C.; Perri, P. The importance of glial cells in the homeostasis of the retinal microenvironment and their pivotal role in the course of diabetic retinopathy. Life Sci. 2016, 162, 54-59. [CrossRef] [PubMed]

149. Zeng, H.Y.; Green, W.R.; Tso, M.O. Microglial activation in human diabetic retinopathy. Arch. Ophthalmol. 2008, 126, 227-232. [CrossRef] [PubMed]

150. Holm, T.H.; Draeby, D.; Owens, T. Microglia are required for astroglial toll-like receptor 4 response and for optimal TLR2 and TLR3 response. Glia 2012, 60, 630-638. [CrossRef] [PubMed]

151. Cuenca, N.; Fernandez-Sanchez, L.; Campello, L.; Maneu, V.; De la Villa, P.; Lax, P.; Pinilla, I. Cellular responses following retinal injuries and therapeutic approaches for neurodegenerative diseases. Prog. Retin. Eye Res. 2014, 43, 17-75. [CrossRef] [PubMed]

152. Greter, M.; Lelios, I.; Croxford, A.L. Microglia versus myeloid cell nomenclature during brain inflammation. Front. Immunol. 2015, 6, 249. [CrossRef] [PubMed]

153. Fernandes, A.; Miller-Fleming, L.; Pais, T.F. Microglia and inflammation: Conspiracy, controversy or control? Cell. Mol. Life Sci. 2014, 71, 3969-3985. [CrossRef] [PubMed]

154. Davis, E.J.; Foster, T.D.; Thomas, W.E. Cellular forms and functions of brain microglia. Brain Res. Bull. 1994, 34, 73-78. [CrossRef]

155. Graeber, M.B.; Li, W.; Rodriguez, M.L. Role of microglia in cns inflammation. FEBS Lett. 2011, 585, 3798-3805. [CrossRef] [PubMed]

156. Ibrahim, A.S.; El-Remessy, A.B.; Matragoon, S.; Zhang, W.; Patel, Y.; Khan, S.; Al-Gayyar, M.M.; El-Shishtawy, M.M.; Liou, G.I. Retinal microglial activation and inflammation induced by amadori-glycated albumin in a rat model of diabetes. Diabetes 2011, 60, 1122-1133. [CrossRef] [PubMed]

157. Grigsby, J.G.; Cardona, S.M.; Pouw, C.E.; Muniz, A.; Mendiola, A.S.; Tsin, A.T.; Allen, D.M.; Cardona, A.E. The role of microglia in diabetic retinopathy. J. Ophthalmol. 2014, 2014, 705783. [CrossRef] [PubMed] 
158. Karlstetter, M.; Scholz, R.; Rutar, M.; Wong, W.T.; Provis, J.M.; Langmann, T. Retinal microglia: Just bystander or target for therapy? Prog. Retin. Eye Res. 2015, 45, 30-57. [CrossRef] [PubMed]

159. Coorey, N.J.; Shen, W.; Chung, S.H.; Zhu, L.; Gillies, M.C. The role of glia in retinal vascular disease. Clin. Exp. Optom. 2012, 95, 266-281. [CrossRef] [PubMed]

160. Bringmann, A.; Pannicke, T.; Grosche, J.; Francke, M.; Wiedemann, P.; Skatchkov, S.N.; Osborne, N.N.; Reichenbach, A. Muller cells in the healthy and diseased retina. Prog. Retin. Eye Res. 2006, 25, 397-424. [CrossRef] [PubMed]

161. Newman, E.; Reichenbach, A. The muller cell: A functional element of the retina. Trends Neurosci. 1996, 19, 307-312. [CrossRef]

162. Eastlake, K.; Banerjee, P.J.; Angbohang, A.; Charteris, D.G.; Khaw, P.T.; Limb, G.A. Muller glia as an important source of cytokines and inflammatory factors present in the gliotic retina during proliferative vitreoretinopathy. Glia 2016, 64, 495-506. [CrossRef] [PubMed]

163. Gerhardinger, C.; Costa, M.B.; Coulombe, M.C.; Toth, I.; Hoehn, T.; Grosu, P. Expression of acute-phase response proteins in retinal muller cells in diabetes. Investig. Ophthalmol. Vis. Sci. 2005, 46, 349-357. [CrossRef] [PubMed]

164. Liu, X.; Ye, F.; Xiong, H.; Hu, D.; Limb, G.A.; Xie, T.; Peng, L.; Yang, W.; Sun, Y.; Zhou, M.; et al. Il-1beta upregulates IL-8 production in human muller cells through activation of the p38 mapk and erk1/2 signaling pathways. Inflammation 2014, 37, 1486-1495. [CrossRef] [PubMed]

165. Ridet, J.L.; Malhotra, S.K.; Privat, A.; Gage, F.H. Reactive astrocytes: Cellular and molecular cues to biological function. Trends Neurosci. 1997, 20, 570-577. [CrossRef]

166. Rungger-Brandle, E.; Messerli, J.M.; Niemeyer, G.; Eppenberger, H.M. Confocal microscopy and computer-assisted image reconstruction of astrocytes in the mammalian retina. Eur. J. Neurosci. 1993, 5, 1093-1106. [CrossRef] [PubMed]

167. Kim, J.H.; Kim, J.H.; Park, J.A.; Lee, S.W.; Kim, W.J.; Yu, Y.S.; Kim, K.W. Blood-neural barrier: Intercellular communication at glio-vascular interface. J. Biochem. Mol. Biol. 2006, 39, 339-345. [CrossRef] [PubMed]

168. Pekny, M.; Wilhelmsson, U.; Pekna, M. The dual role of astrocyte activation and reactive gliosis. Neurosci. Lett. 2014, 565, 30-38. [CrossRef] [PubMed]

169. Shin, E.S.; Huang, Q.; Gurel, Z.; Sorenson, C.M.; Sheibani, N. High glucose alters retinal astrocytes phenotype through increased production of inflammatory cytokines and oxidative stress. PLoS ONE 2014, 9, e103148. [CrossRef] [PubMed]

170. Rothhammer, V.; Quintana, F.J. Control of autoimmune cns inflammation by astrocytes. Semin. Immunopathol. 2015, 37, 625-638. [CrossRef] [PubMed]

171. Lieth, E.; LaNoue, K.F.; Berkich, D.A.; Xu, B.; Ratz, M.; Taylor, C.; Hutson, S.M. Nitrogen shuttling between neurons and glial cells during glutamate synthesis. J. Neurochem. 2001, 76, 1712-1723. [CrossRef] [PubMed]

172. Orkand, R.K.; Nicholls, J.G.; Kuffler, S.W. Effect of nerve impulses on the membrane potential of glial cells in the central nervous system of amphibia. J. Neurophysiol. 1966, 29, 788-806. [CrossRef] [PubMed]

173. Uckermann, O.; Wolf, A.; Kutzera, F.; Kalisch, F.; Beck-Sickinger, A.G.; Wiedemann, P.; Reichenbach, A.; Bringmann, A. Glutamate release by neurons evokes a purinergic inhibitory mechanism of osmotic glial cell swelling in the rat retina: Activation by neuropeptide y. J. Neurosci. Res. 2006, 83, 538-550. [CrossRef] [PubMed]

174. Metea, M.R.; Newman, E.A. Glial cells dilate and constrict blood vessels: A mechanism of neurovascular coupling. J. Neurosci. 2006, 26, 2862-2870. [CrossRef] [PubMed]

175. Chang, M.L.; Wu, C.H.; Jiang-Shieh, Y.F.; Shieh, J.Y.; Wen, C.Y. Reactive changes of retinal astrocytes and muller glial cells in kainate-induced neuroexcitotoxicity. J. Anat. 2007, 210, 54-65. [CrossRef] [PubMed]

176. Kettenmann, H.; Kirchhoff, F.; Verkhratsky, A. Microglia: New roles for the synaptic stripper. Neuron 2013, 77, 10-18. [CrossRef] [PubMed]

177. Bilimoria, P.M.; Stevens, B. Microglia function during brain development: New insights from animal models. Brain Res. 2015, 1617, 7-17. [CrossRef] [PubMed]

178. Fu, S.; Dong, S.; Zhu, M.; Sherry, D.M.; Wang, C.; You, Z.; Haigh, J.J.; Le, Y.Z. Muller glia are a major cellular source of survival signals for retinal neurons in diabetes. Diabetes 2015, 64, 3554-3563. [CrossRef] [PubMed]

179. Bringmann, A.; Iandiev, I.; Pannicke, T.; Wurm, A.; Hollborn, M.; Wiedemann, P.; Osborne, N.N.; Reichenbach, A. Cellular signaling and factors involved in muller cell gliosis: Neuroprotective and detrimental effects. Prog. Retin. Eye Res. 2009, 28, 423-451. [CrossRef] [PubMed] 
180. Roy, S.; Amin, S.; Roy, S. Retinal fibrosis in diabetic retinopathy. Exp. Eye Res. 2016, 142, 71-75. [CrossRef] [PubMed]

181. Fogal, B.; Hewett, S.J. Interleukin-1beta: A bridge between inflammation and excitotoxicity? J. Neurochem. 2008, 106, 1-23. [CrossRef] [PubMed]

182. Tezel, G. Tnf-alpha signaling in glaucomatous neurodegeneration. Prog. Brain Res. 2008, 173, 409-421. [PubMed]

183. Abcouwer, S.F.; Shanmugam, S.; Gomez, P.F.; Shushanov, S.; Barber, A.J.; Lanoue, K.F.; Quinn, P.G.; Kester, M.; Gardner, T.W. Effect of IL-1beta on survival and energy metabolism of R28 and RGC-5 retinal neurons. Investig. Ophthalmol. Vis. Sci. 2008, 49, 5581-5592. [CrossRef] [PubMed]

184. Sheridan, G.K.; Murphy, K.J. Neuron-glia crosstalk in health and disease: Fractalkine and CX3CR1 take centre stage. Open Biol. 2013, 3, 130181. [CrossRef] [PubMed]

185. Cui, B.; Sun, J.H.; Xiang, F.F.; Liu, L.; Li, W.J. Aquaporin 4 knockdown exacerbates streptozotocin-induced diabetic retinopathy through aggravating inflammatory response. Exp. Eye Res. 2012, 98, 37-43. [CrossRef] [PubMed]

186. Gariano, R.F.; Gardner, T.W. Retinal angiogenesis in development and disease. Nature 2005, 438, 960-966. [CrossRef] [PubMed]

187. Tolentino, M.J.; McLeod, D.S.; Taomoto, M.; Otsuji, T.; Adamis, A.P.; Lutty, G.A. Pathologic features of vascular endothelial growth factor-induced retinopathy in the nonhuman primate. Am. J. Ophthalmol. 2002, 133, 373-385. [CrossRef]

188. Simo, R.; Hernandez, C. Novel approaches for treating diabetic retinopathy based on recent pathogenic evidence. Prog. Retin. Eye Res. 2015, 48, 160-180. [CrossRef] [PubMed]

189. Unterlauft, J.D.; Claudepierre, T.; Schmidt, M.; Muller, K.; Yafai, Y.; Wiedemann, P.; Reichenbach, A.; Eichler, W. Enhanced survival of retinal ganglion cells is mediated by muller glial cell-derived PEDF. Exp. Eye Res. 2014, 127, 206-214. [CrossRef] [PubMed]

190. Unterlauft, J.D.; Eichler, W.; Kuhne, K.; Yang, X.M.; Yafai, Y.; Wiedemann, P.; Reichenbach, A.; Claudepierre, T. Pigment epithelium-derived factor released by muller glial cells exerts neuroprotective effects on retinal ganglion cells. Neurochem. Res. 2012, 37, 1524-1533. [CrossRef] [PubMed]

191. Mu, H.; Zhang, X.M.; Liu, J.J.; Dong, L.; Feng, Z.L. Effect of high glucose concentration on VEGF and PEDF expression in cultured retinal muller cells. Mol. Biol. Rep. 2009, 36, 2147-2151. [CrossRef] [PubMed]

192. Lange, J.; Yafai, Y.; Reichenbach, A.; Wiedemann, P.; Eichler, W. Regulation of pigment epithelium-derived factor production and release by retinal glial (muller) cells under hypoxia. Investig. Ophthalmol. Vis. Sci. 2008, 49, 5161-5167. [CrossRef] [PubMed]

193. Sakaguchi, H.; Miyagi, M.; Darrow, R.M.; Crabb, J.S.; Hollyfield, J.G.; Organisciak, D.T.; Crabb, J.W. Intense light exposure changes the crystallin content in retina. Exp. Eye Res. 2003, 76, 131-133. [CrossRef]

194. Sax, C.M.; Piatigorsky, J. Expression of the alpha-crystallin/small heat-shock protein/molecular chaperone genes in the lens and other tissues. Adv. Enzymol. Relat. Areas Mol. Biol. 1994, 69, 155-201. [PubMed]

195. Rao, N.A.; Saraswathy, S.; Wu, G.S.; Katselis, G.S.; Wawrousek, E.F.; Bhat, S. Elevated retina-specific expression of the small heat shock protein, alphaa-crystallin, is associated with photoreceptor protection in experimental uveitis. Investig. Ophthalmol. Vis. Sci. 2008, 49, 1161-1171. [CrossRef] [PubMed]

196. Steele, M.R.; Inman, D.M.; Calkins, D.J.; Horner, P.J.; Vetter, M.L. Microarray analysis of retinal gene expression in the DBA/2J model of glaucoma. Investig. Ophthalmol. Vis. Sci. 2006, 47, 977-985. [CrossRef] [PubMed]

197. Vazquez-Chona, F.; Song, B.K.; Geisert, E.E., Jr. Temporal changes in gene expression after injury in the rat retina. Investig. Ophthalmol. Vis. Sci. 2004, 45, 2737-2746. [CrossRef] [PubMed]

198. Ruebsam, A.; Dulle, J.E.; Myers, A.M.; Sakrikar, D.; Green, K.M.; Khan, N.W.; Schey, K.; Fort, P.E. A specific phosphorylation regulates the protective role of alphaa-crystallin in diabetes. JCI Insight 2018, 3. [CrossRef] [PubMed]

199. Lowe, J.; Landon, M.; Pike, I.; Spendlove, I.; McDermott, H.; Mayer, R.J. Dementia with beta-amyloid deposition: Involvement of alpha b-crystallin supports two main diseases. Lancet 1990, 336, 515-516. [CrossRef]

200. Renkawek, K.; Voorter, C.E.; Bosman, G.J.; van Workum, F.P.; de Jong, W.W. Expression of alpha b-crystallin in Alzheimer's disease. Acta Neuropathol. 1994, 87, 155-160. [CrossRef] [PubMed] 
201. Iwaki, T.; Wisniewski, T.; Iwaki, A.; Corbin, E.; Tomokane, N.; Tateishi, J.; Goldman, J.E. Accumulation of alpha b-crystallin in central nervous system glia and neurons in pathologic conditions. Am. J. Pathol. 1992, 140, 345-356. [PubMed]

202. Kegel, K.B.; Iwaki, A.; Iwaki, T.; Goldman, J.E. Alphab-crystallin protects glial cells from hypertonic stress. Am. J. Physiol. 1996, 270, C903-C909. [CrossRef] [PubMed]

203. Parks, W.C.; Wilson, C.L.; Lopez-Boado, Y.S. Matrix metalloproteinases as modulators of inflammation and innate immunity. Nat. Rev. Immunol. 2004, 4, 617-629. [CrossRef] [PubMed]

204. Stamenkovic, I. Extracellular matrix remodelling: The role of matrix metalloproteinases. J. Pathol. 2003, 200, 448-464. [CrossRef] [PubMed]

205. Jin, M.; Kashiwagi, K.; Iizuka, Y.; Tanaka, Y.; Imai, M.; Tsukahara, S. Matrix metalloproteinases in human diabetic and nondiabetic vitreous. Retina 2001, 21, 28-33. [CrossRef] [PubMed]

206. Yang, R.; Liu, H.; Williams, I.; Chaqour, B. Matrix metalloproteinase-2 expression and apoptogenic activity in retinal pericytes: Implications in diabetic retinopathy. Ann. N. Y. Acad. Sci. 2007, 1103, 196-201. [CrossRef] [PubMed]

207. Zhang, H.; Trivedi, A.; Lee, J.U.; Lohela, M.; Lee, S.M.; Fandel, T.M.; Werb, Z.; Noble-Haeusslein, L.J. Matrix metalloproteinase- 9 and stromal cell-derived factor-1 act synergistically to support migration of blood-borne monocytes into the injured spinal cord. J. Neurosci. 2011, 31, 15894-15903. [CrossRef] [PubMed]

208. Navaratna, D.; McGuire, P.G.; Menicucci, G.; Das, A. Proteolytic degradation of VE-cadherin alters the blood-retinal barrier in diabetes. Diabetes 2007, 56, 2380-2387. [CrossRef] [PubMed]

209. Lee, C.Z.; Xue, Z.; Zhu, Y.; Yang, G.Y.; Young, W.L. Matrix metalloproteinase-9 inhibition attenuates vascular endothelial growth factor-induced intracerebral hemorrhage. Stroke 2007, 38, 2563-2568. [CrossRef] [PubMed]

210. Kawasaki, T.; Kawai, T. Toll-like receptor signaling pathways. Front. Immunol. 2014, 5, 461. [CrossRef] [PubMed]

211. Kim, J.J.; Sears, D.D. TLR4 and insulin resistance. Gastroenterol. Res. Pract. 2010, 2010, 212563. [CrossRef] [PubMed]

212. Van Beijnum, J.R.; Buurman, W.A.; Griffioen, A.W. Convergence and amplification of toll-like receptor (TLR) and receptor for advanced glycation end products (rage) signaling pathways via high mobility group b1 (HMGB1). Angiogenesis 2008, 11, 91-99. [CrossRef] [PubMed]

213. Feng, L.; Ju, M.; Lee, K.Y.V.; Mackey, A.; Evangelista, M.; Iwata, D.; Adamson, P.; Lashkari, K.; Foxton, R.; Shima, D.; et al. A proinflammatory function of toll-like receptor 2 in the retinal pigment epithelium as a novel target for reducing choroidal neovascularization in age-related macular degeneration. Am. J. Pathol. 2017, 187, 2208-2221. [CrossRef] [PubMed]

214. Rajamani, U.; Jialal, I. Hyperglycemia induces toll-like receptor-2 and -4 expression and activity in human microvascular retinal endothelial cells: Implications for diabetic retinopathy. J. Diabetes Res. 2014, 2014, 790902. [CrossRef] [PubMed]

215. Gao, B.B.; Chen, X.; Timothy, N.; Aiello, L.P.; Feener, E.P. Characterization of the vitreous proteome in diabetes without diabetic retinopathy and diabetes with proliferative diabetic retinopathy. J. Proteome Res. 2008, 7, 2516-2525. [CrossRef] [PubMed]

216. Garcia-Ramirez, M.; Canals, F.; Hernandez, C.; Colome, N.; Ferrer, C.; Carrasco, E.; Garcia-Arumi, J.; Simo, R. Proteomic analysis of human vitreous fluid by fluorescence-based difference gel electrophoresis (DIGE): A new strategy for identifying potential candidates in the pathogenesis of proliferative diabetic retinopathy. Diabetologia 2007, 50, 1294-1303. [CrossRef] [PubMed]

217. Cheng, L.; Bu, H.; Portillo, J.A.; Li, Y.; Subauste, C.S.; Huang, S.S.; Kern, T.S.; Lin, F. Modulation of retinal muller cells by complement receptor c5ar. Investig. Ophthalmol. Vis. Sci. 2013, 54, 8191-8198. [CrossRef] [PubMed]

218. King, P.; Peacock, I.; Donnelly, R. The uk prospective diabetes study (UKPDS): Clinical and therapeutic implications for type 2 diabetes. Br. J. Clin. Pharmacol. 1999, 48, 643-648. [CrossRef] [PubMed]

219. The effect of intensive diabetes treatment on the progression of diabetic retinopathy in insulin-dependent diabetes mellitus. The diabetes control and complications trial. Arch. Ophthalmol. 1995, 113, 36-51.

220. Cunningham, M.A.; Edelman, J.L.; Kaushal, S. Intravitreal steroids for macular edema: The past, the present, and the future. Surv. Ophthalmol. 2008, 53, 139-149. [CrossRef] [PubMed] 
221. Jonas, J.B. Intravitreal triamcinolone acetonide for diabetic retinopathy. Dev. Ophthalmol. 2007, 39, 96-110. [PubMed]

222. Joussen, A.M.; Poulaki, V.; Mitsiades, N.; Kirchhof, B.; Koizumi, K.; Dohmen, S.; Adamis, A.P. Nonsteroidal anti-inflammatory drugs prevent early diabetic retinopathy via TNF-alpha suppression. FASEB J. 2002, 16, 438-440. [CrossRef] [PubMed]

223. Du, Y.; Sarthy, V.P.; Kern, T.S. Interaction between NO and COX pathways in retinal cells exposed to elevated glucose and retina of diabetic rats. Am. J. Physiol. Regul. Integr. Comp. Physiol. 2004, 287, R735-R741. [CrossRef] [PubMed]

224. Early Treatment Diabetic Retinopathy Study Research Group. Effects of aspirin treatment on diabetic retinopathy. Etdrs report number 8. Ophthalmology 1991, 98, 757-765.

225. The Damad Study Group. Effect of aspirin alone and aspirin plus dipyridamole in early diabetic retinopathy. A multicenter randomized controlled clinical trial. Diabetes 1989, 38, 491-498.

226. Kim, S.J.; Flach, A.J.; Jampol, L.M. Nonsteroidal anti-inflammatory drugs in ophthalmology. Surv. Ophthalmol. 2010, 55, 108-133. [CrossRef] [PubMed]

227. Kern, T.S.; Miller, C.M.; Du, Y.; Zheng, L.; Mohr, S.; Ball, S.L.; Kim, M.; Jamison, J.A.; Bingaman, D.P. Topical administration of nepafenac inhibits diabetes-induced retinal microvascular disease and underlying abnormalities of retinal metabolism and physiology. Diabetes 2007, 56, 373-379. [CrossRef] [PubMed]

228. Amrite, A.C.; Ayalasomayajula, S.P.; Cheruvu, N.P.; Kompella, U.B. Single periocular injection of celecoxib-plga microparticles inhibits diabetes-induced elevations in retinal PGE2, VEGF, and vascular leakage. Investig. Ophthalmol. Vis. Sci. 2006, 47, 1149-1160. [CrossRef] [PubMed]

229. Tsilimbaris, M.K.; Panagiotoglou, T.D.; Charisis, S.K.; Anastasakis, A.; Krikonis, T.S.; Christodoulakis, E. The use of intravitreal etanercept in diabetic macular oedema. Semin. Ophthalmol. 2007, 22, 75-79. [CrossRef] [PubMed]

230. Sfikakis, P.P.; Markomichelakis, N.; Theodossiadis, G.P.; Grigoropoulos, V.; Katsilambros, N.; Theodossiadis, P.G. Regression of sight-threatening macular edema in type 2 diabetes following treatment with the anti-tumor necrosis factor monoclonal antibody infliximab. Diabetes Care 2005, 28, 445-447. [CrossRef] [PubMed]

231. Stahel, M.; Becker, M.; Graf, N.; Michels, S. Systemic interleukin 1beta inhibition in proliferative diabetic retinopathy: A prospective open-label study using canakinumab. Retina 2016, 36, 385-391. [CrossRef] [PubMed]

232. A Phase 2, Multi-Center Study to Compare the Efficacy and Safety of a Chemokine CCR2/5 Receptor Antagonist with Ranibizumab in Adults Withdiabetic Macular Edema. Available online: https:/ clinicaltrials. gov/ct2/show/NCT01994291 (accessed on 30 October 2017).

233. Ulbrich, H.; Eriksson, E.E.; Lindbom, L. Leukocyte and endothelial cell adhesion molecules as targets for therapeutic interventions in inflammatory disease. Trends Pharmacol. Sci. 2003, 24, 640-647. [CrossRef] [PubMed]

234. Allegro Ophthalmics Announces Positive Topline Results from Del Mar Phase 2b Trial Evaluating Luminate®in Patients with Diabetic Macular Edema. Available online: http:/ / www.allegroeye.com/press (accessed on 30 October 2017).

235. Fiedler, U.; Reiss, Y.; Scharpfenecker, M.; Grunow, V.; Koidl, S.; Thurston, G.; Gale, N.W.; Witzenrath, M.; Rosseau, S.; Suttorp, N.; et al. Angiopoietin-2 sensitizes endothelial cells to tnf-alpha and has a crucial role in the induction of inflammation. Nat. Med. 2006, 12, 235-239. [CrossRef] [PubMed]

236. The Time-2b Study: A Study of Akb-9778, a Novel Tie 2 Activator, in Patients with Non-Proliferative Diabetic Retinopathy (NPDR) (Time-2b). Available online: https://clinicaltrials.gov/ct2/show/NCT03197870 (accessed on 30 October 2017).

237. Sjolie, A.K.; Klein, R.; Porta, M.; Orchard, T.; Fuller, J.; Parving, H.H.; Bilous, R.; Chaturvedi, N.; DIRECT Programme Study Group. Effect of candesartan on progression and regression of retinopathy in type 2 diabetes (direct-protect 2): A randomised placebo-controlled trial. Lancet 2008, 372, 1385-1393. [CrossRef]

238. Mauer, M.; Zinman, B.; Gardiner, R.; Suissa, S.; Sinaiko, A.; Strand, T.; Drummond, K.; Donnelly, S.; Goodyer, P.; Gubler, M.C.; et al. Renal and retinal effects of enalapril and losartan in type 1 diabetes. N. Engl. J. Med. 2009, 361, 40-51. [CrossRef] [PubMed]

239. Garrido-Mesa, N.; Zarzuelo, A.; Galvez, J. Minocycline: Far beyond an antibiotic. Br. J. Pharmacol. 2013, 169, 337-352. [CrossRef] [PubMed] 
240. Domercq, M.; Matute, C. Neuroprotection by tetracyclines. Trends Pharmacol. Sci. 2004, 25, 609-612. [CrossRef] [PubMed]

241. Bernardino, A.L.; Kaushal, D.; Philipp, M.T. The antibiotics doxycycline and minocycline inhibit the inflammatory responses to the lyme disease spirochete borrelia burgdorferi. J. Infect. Dis. 2009, 199, 1379-1388. [CrossRef] [PubMed]

242. Cukras, C.A.; Petrou, P.; Chew, E.Y.; Meyerle, C.B.; Wong, W.T. Oral minocycline for the treatment of diabetic macular edema (DME): Results of a phase I/II clinical study. Investig. Ophthalmol. Vis. Sci. 2012, 53, 3865-3874. [CrossRef] [PubMed]

243. Lachin, J.M.; Genuth, S.; Nathan, D.M.; Zinman, B.; Rutledge, B.N.; Group, D.E.R. Effect of glycemic exposure on the risk of microvascular complications in the diabetes control and complications trial-Revisited. Diabetes 2008, 57, 995-1001. [CrossRef] [PubMed]

244. Tang, J.; Du, Y.; Lee, C.A.; Talahalli, R.; Eells, J.T.; Kern, T.S. Low-intensity far-red light inhibits early lesions that contribute to diabetic retinopathy: In vivo and in vitro. Investig. Ophthalmol. Vis. Sci. 2013, 54, 3681-3690. [CrossRef] [PubMed]

245. Tang, J.; Herda, A.A.; Kern, T.S. Photobiomodulation in the treatment of patients with non-center-involving diabetic macular oedema. Br. J. Ophthalmol. 2014, 98, 1013-1015. [CrossRef] [PubMed]

(C) 2018 by the authors. Licensee MDPI, Basel, Switzerland. This article is an open access article distributed under the terms and conditions of the Creative Commons Attribution (CC BY) license (http:/ / creativecommons.org/licenses/by/4.0/). 